



\section{Broeikasgasemissie van de Gelderse land- en tuinbouw in 2016}

Leonne Jeurissen, Jan Cees Voogd, Hans Kros en Jan Peter Lesschen

Dit onderzoek is uitgevoerd door Wageningen Environmental Research in opdracht van en gefinancierd door de provincie Gelderland.

Wageningen Environmental Research

Wageningen, april 2019

Gereviewd door:

Gert Jan Reinds, Teamleider (Wageningen Environmental Research)

Akkoord voor publicatie:

Gert Jan Reinds, teamleider van team Duurzaam Bodemgebruik

Rapport 2947

ISSN 1566-7197 
Jeurissen L.J.J., J.C.H. Voogd, J. Kros, J.P. Lesschen, 2019. Broeikasgasemissie van de Gelderse landen tuinbouw in 2016. Wageningen, Wageningen Environmental Research, Rapport 2947. 54 blz.; 6 fig.; 13 tab.; 13 ref.

Provinciale Staten van Gelderland hebben de ambitie vastgesteld om in 2030 de uitstoot van broeikasgassen in Gelderland 55\% lager te laten zijn dan in 1990. Om deze ambitie te kunnen ondersteunen, is er vanuit het Gelders Energieakkoord (GEA) behoefte om de uitstoot van broeikasgassen vanuit de land- en tuinbouw per gemeente te monitoren. In dit onderzoek is een actualisatie uitgevoerd voor het peiljaar 2016/2017. Zo is per Gelderse gemeente de broeikasgasemissie in kaart gebracht voor de belangrijkste agrosectoren, waaronder de melkveehouderij, vleeskalverhouderij, varkenshouderij, pluimveehouderij, akker- en tuinbouw en glastuinbouw. De berekeningen van de broeikasgasemissie zijn uitgevoerd met het model INITIATOR op gemeenteniveau volgens de nationale systematiek (NEMA) voor het rapporteren van broeikasgasemissie. De totale broeikasgasemissie uit de landbouw in Gelderland bedraagt 3,5 Mton $\mathrm{CO}_{2}$-equivalenten. De sector met de grootste broeikasgasemissie is de melkveehouderij (50\%), met als grootste bronnen de methaanemissie door pensfermentatie (54\%) en mestmanagement (15\%). Ten opzichte van 2005 is de totale broeikasgasemissie in 2016/2017 min of meer gelijk gebleven. Wel zijn er verschuivingen tussen sectoren opgetreden. De methodiek is zo opgezet dat ook voor komende jaren gemakkelijk een berekening kan worden uitgevoerd, waarmee dit een vast onderdeel van de GEA-rapportage kan vormen.

Trefwoorden: Broeikasgassen, emissies, landbouw, agrosectoren, Gelderland

Dit rapport is gratis te downloaden van https://doi.org/10.18174/476296 of op www.wur.nl/environmental-research (ga naar 'Wageningen Environmental Research' in de grijze balk onderaan). Wageningen Environmental Research verstrekt geen gedrukte exemplaren van rapporten.

2019 Wageningen Environmental Research (instituut binnen de rechtspersoon Stichting Wageningen Research), Postbus 47, 6700 AA Wageningen, T 03174807 00, www.wur.nl/environmental-research. Wageningen Environmental Research is onderdeel van Wageningen University \& Research.

- Overname, verveelvoudiging of openbaarmaking van deze uitgave is toegestaan mits met duidelijke bronvermelding.

- Overname, verveelvoudiging of openbaarmaking is niet toegestaan voor commerciële doeleinden en/of geldelijk gewin.

- Overname, verveelvoudiging of openbaarmaking is niet toegestaan voor die gedeelten van deze uitgave waarvan duidelijk is dat de auteursrechten liggen bij derden en/of zijn voorbehouden.

Wageningen Environmental Research aanvaardt geen aansprakelijkheid voor eventuele schade voortvloeiend uit het gebruik van de resultaten van dit onderzoek of de toepassing van de adviezen.

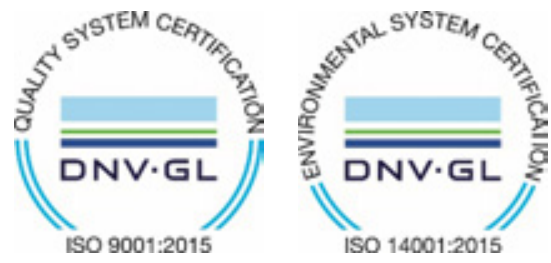

Wageningen Environmental Research werkt sinds 2003 met een ISO 9001 gecertificeerd kwaliteitsmanagementsysteem. In 2006 heeft Wageningen Environmental Research een milieuzorgsysteem geïmplementeerd, gecertificeerd volgens de norm ISO 14001.

Wageningen Environmental Research geeft via ISO 26000 invulling aan haar maatschappelijke verantwoordelijkheid.

Wageningen Environmental Research Rapport 2947 | ISSN 1566-7197

Foto omslag: Shutterstock 


\section{Inhoud}

Verantwoording $\quad 5$

$\begin{array}{ll}\text { Samenvatting } & 7\end{array}$

$\begin{array}{llr}1 & \text { Introductie } & 9\end{array}$

1.1 Probleemstelling 99

1.2 Doel 9

$\begin{array}{lll}1.3 & \text { Aanpak en afbakening } & 9\end{array}$

$2 \quad$ Bronnen van broeikasgasemissies in de landbouw $\quad 11$

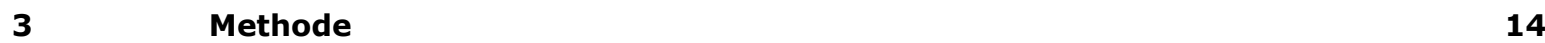

3.1 Methode voor de berekening van broeikasgasemissies $\quad 14$

3.1.1 Aanpak 14

3.1.2 Lachgasemissie $\quad 16$

$\begin{array}{ll}3.1 .3 \text { Methaanemissie } & 17\end{array}$

3.1.4 $\mathrm{CO}_{2}$-emissie door energieverbruik 18

$\begin{array}{ll}3.1 .5 \text { Broeikasgasemissies glastuinbouw } & 19\end{array}$

$4 \quad$ Broeikasgasemissies uit de landbouw in $2016 \quad 21$

$\begin{array}{lll}4.1 & \text { Broeikasgasemissies per sector } & 21\end{array}$

4.2 Broeikasgasemissies per bron $\quad 22$

$\begin{array}{lll}4.3 & \text { Ruimtelijke verdeling van broeikasgasemissies } & 23\end{array}$

$5 \quad$ Vergelijking broeikasgasemissies 2005 en $2016 \quad 25$

$\begin{array}{llr}6 & \text { Conclusies en aanbevelingen } & 27\end{array}$

$\begin{array}{ll}\text { Literatuur } & \mathbf{2 8}\end{array}$

Bijlage 1 Korte beschrijving van het model INITIATOR 29

$\begin{array}{lll}\text { Bijlage } 2 & \text { Indeling diercategorieën INITIATOR } & 31\end{array}$

Bijlage 3 Broeikasgasemissies in Gelderland in 2016/2017 naar sector en naar bron (in kton $\mathrm{N}_{2} \mathrm{O}$, kton $\mathrm{CH}_{4}$ of kton $\mathrm{CO}_{2}$-equivalenten) 32

Bijlage 4 Broeikasgasemissies per regio en per gemeente naar sector in 2016/2017 (in eigen eenheid en in kton $\mathrm{CO}_{2}$-equivalenten) 



\section{Verantwoording}

Rapport: 2947

Projectnummer: 5200045184

Wageningen Environmental Research (WENR) hecht grote waarde aan de kwaliteit van onze eindproducten. Een review van de rapporten op wetenschappelijke kwaliteit door een referent maakt standaard onderdeel uit van ons kwaliteitsbeleid.

Akkoord Referent die het heeft beoordeeld,

functie: $\quad$ Teamleider

naam: Gert Jan Reinds

datum: $\quad$ 8-4-2019

Akkoord teamleider voor de inhoud,

naam: Gert Jan Reinds

datum: 19-4-2019 


\section{Samenvatting}

In opdracht van de provincie Gelderland en ten behoeve van de monitoring van het Gelders Energieakkoord (GEA) zijn de broeikasgasemissies in de Gelderse landbouw gekwantificeerd op gemeenteniveau voor het peiljaar 2016/2017. Verschillende agrosectoren en verschillende bronnen zijn onderscheiden.

Voor het berekenen van emissies van de broeikasgassen lachgas $\left(\mathrm{N}_{2} \mathrm{O}\right)$ en methaan $\left(\mathrm{CH}_{4}\right)$ vanuit de landbouw is gebruikgemaakt van het model INITIATOR. De emissies zijn berekend per gemeente, per bedrijfstype en per emissiebron. Voor glastuinbouw is een grove schatting gemaakt van de emissie op gemeenteniveau door gebruik te maken van de nationale gegevens en deze per hectare neer te schalen per gemeente. Voor de andere landbouwsectoren is de $\mathrm{CO}_{2}$-emissie t.g.v. energieverbruik per gemeente gebaseerd op het landelijk gemiddelde energieverbruik per bedrijf voor de verschillende sectoren zoals bepaald in het Bedrijveninformatienet. Ook dit is een grove schatting.

De totale broeikasgasemissie uit de landbouw in Gelderland bedraagt 3,5 Mton $\mathrm{CO}_{2}$-equivalenten; dit is $13,6 \%$ van de landbouwemissies in Nederland. De sector met de grootste broeikasgasemissie is de melkveehouderij (50\%), met als grootste bronnen de methaanemissie door pensfermentatie (54\%) en mestmanagement (15\%). De emissie door energiegebruik is het grootst bij de glastuinbouw. De emissie van broeikasgassen is niet gelijk verdeeld over Gelderland. Hoge broeikasgasemissies komen voor in de Gelderse Vallei (Harderwijk tot Ede) ten gevolge van intensieve veehouderij en in Zaltbommel en de Lingewaard door de glastuinbouw.

Ten opzichte van 2005 is de totale broeikasgasemissie in 2016/2017 min of meer gelijk gebleven. Wel zijn er verschuivingen tussen sectoren opgetreden, met hogere emissies uit de melkveehouderij en vleeskalverhouderij en afname van de emissies in de pluimveehouderij, vleesveehouderij en de glastuinbouw. Deels is dit het gevolg van veranderingen in dieraantallen, maar deels zijn de verschillen ook het gevolg van afwijkende methodieken in de nulmeting en deze studie.

De komende jaren kan monitoring van de broeikasgasemissies uit de landbouw volgens de methodiek zoals beschreven in dit rapport worden uitgevoerd. Aanbevolen wordt om te kijken of de emissies door energieverbruik op een gedetailleerdere wijze op gemeenteniveau bepaald kunnen worden. Deze rapportage biedt goed inzicht in de huidige omvang van de emissies voor de verschillende sectoren en emissiebronnen en kan daarmee dienen voor het prioriteren van mogelijke maatregelen om broeikasgasemissies te verminderen. De methodiek is zo opgezet dat ook voor komende jaren gemakkelijk een berekening kan worden uitgevoerd van de emissies uit de land- en tuinbouwsector in Gelderland, waarmee dit een vast onderdeel van de GEA-rapportage kan vormen. 


\section{$1 \quad$ Introductie}

\section{$1.1 \quad$ Probleemstelling}

Provinciale Staten van Gelderland hebben de ambitie vastgesteld om in 2030 de uitstoot van broeikasgassen in Gelderland 55\% lager te laten zijn dan in 1990. Vanuit het Gelders Energieakkoord (GEA) - de in oprichting zijnde tafel Landbouw en Landgebruik - is de behoefte getoond om de uitstoot van broeikasgassen vanuit de land- en tuinbouw per gemeente te kunnen monitoren. De provincie is als partner deel van het GEA.

De provincie draagt graag bij aan het inzicht in de emissies en energiegebruik binnen Gelderland door de gegevens van land- en tuinbouwsector toe te voegen aan de reeds bestaande GEA-monitoringssystematiek. In eerste instantie gaat het daarbij om de cijfers op provinciaal, regionaal en gemeentelijk niveau. Het op te leveren resultaat kan een basis vormen voor onderbouwing en verdere inhoudelijke analyse voor het verminderen van de broeikasgasemissies uit de land- en tuinbouwsector, in het licht van een transitie naar klimaatneutrale landbouwsystemen.

In 2009 heeft Alterra (nu Wageningen Environmental Research) in opdracht van de provincie de broeikasgasemissies uit de landbouw en landgebruik voor het jaar 1990 en 2005 gekwantificeerd: de nulmeting (Lesschen et al., 2009). De provincie wil nu een update van de broeikasgasemissiecijfers van deze nulmeting, waarbij de opzet zodanig is dat vervolgberekeningen (voor de jaren die komen) makkelijk gaan en vergelijkbare resultaten opleveren.

\subsection{Doel}

Het doel is het op gemeenteniveau kwantificeren en ruimtelijk in beeld brengen van de broeikasgasemissies uit de land- en tuinbouw voor verschillende agrosectoren voor het peiljaar 2016.

\subsection{Aanpak en afbakening}

Voor het bereken van emissies van de broeikasgassen lachgas $\left(\mathrm{N}_{2} \mathrm{O}\right)$, methaan $\left(\mathrm{CH}_{4}\right)$ en koolzuurgas $\left(\mathrm{CO}_{2}\right)$ vanuit de landbouw is gebruikgemaakt van het model INITIATOR (De Vries et al., 2003; Kros et al., 2011). Dit model is vergelijkbaar met het model MITERRA-NL, wat voor de nulmeting (Lesschen et al., 2009) is gebruikt. Er is nu gekozen voor het model INITIATOR, omdat dit model in het kader van nationale evaluaties wordt ingezet voor het berekenen van de ruimtelijke verdeling van mesttoediening, ammoniak- en broeikasgasemissies (Kros et al., 2018) en de meest actuele en gedetailleerde data over dieraantallen en gewasarealen etc. beschikbaar heeft.

De broeikasgasemissies worden berekend voor de verschillende broeikasgassen afzonderlijk en als totaal uitgedrukt in $\mathrm{CO}_{2}$-equivalenten. Per agrosector wordt zowel de totale emissie als de emissie per hectare landbouwgrond berekend. De volgende agrosectoren worden onderscheiden:

melkveehouderij; vleesveehouderij; vleeskalverhouderij; varkenshouderij; pluimveehouderij; overige veehouderij en gemengde bedrijven; akkerbouw; tuinbouw; blijvende teelten en glastuinbouw. Voor energie-gerelateerde emissies is het peiljaar 2017 en voor de overige broeikasgasemissies 2016.

Van de emissies door energiegebruik in de glastuinbouwsector wordt een grove inschatting gemaakt door gebruik te maken van de nationale gegevens en deze per hectare neer te schalen per gemeente. Uit informatie van collega's van Wageningen Economic Research (WECR), die ook de nationale energiemonitor van de glastuinbouw uitvoeren (van der Velden en Smit, 2018) blijkt namelijk dat deze data niet per gemeente beschikbaar zijn, onder meer vanwege de vertrouwelijkheid ervan. Van de 
emissies door energiegebruik in de overige landbouwsectoren is een grove inschatting gemaakt op basis van het nationale gemiddelde gebruik per bedrijf per bedrijfstype op basis van het Bedrijveninformatienet (BIN) van WECR.

Veranderingen in de koolstofemissie en -vastlegging in bodem en in landgebruik, de emissiesector LULUCF, worden niet meegenomen in dit project. Emissies uit veengronden kunnen een belangrijke bron van emissies gerelateerd aan de landbouw zijn, maar het areaal veengronden binnen de provincie Gelderland is zeer beperkt.

De emissies zijn berekend conform de nationale emissieregistratie voor de rapportages richting EU en UNFCCC. Dit betekent dat alleen de emissies die in Nederland plaatsvinden worden meegenomen. Emissies gerelateerd aan de voerketen (bijv. productie van krachtvoer en import van soja) en de verwerkende industrie zijn niet meegenomen in deze studie, in tegenstelling tot studies die gericht zijn op emissies in de gehele keten, zoals deze vaak met Leven Cyclus Analyse (LCA) worden uitgevoerd. 


\section{Bronnen van broeikasgasemissies in de landbouw}

De land- en tuinbouwsector draagt bij aan de emissies van de broeikasgassen kooldioxide $\left(\mathrm{CO}_{2}\right)$, methaan $\left(\mathrm{CH}_{4}\right)$ en lachgas $\left(\mathrm{N}_{2} \mathrm{O}\right)$. Landbouw is in Nederland een van de grootste bronnen van lachgas en methaan. Glastuinbouw, energiegebruik en emissies uit veengronden zijn binnen de landbouw de belangrijkste bron van $\mathrm{CO}_{2}$.

De Nederlandse nationale rapportage voor broeikasgasemissies onderscheidt drie belangrijke bronnen van broeikasgassen binnen de emissiesector landbouw:

1. $\mathrm{CH}_{4}$-emissies door pensfermentatie

2. $\mathrm{CH}_{4}$-en $\mathrm{N}_{2} \mathrm{O}$-emissies uit mestopslagen

3. $\mathrm{N}_{2} \mathrm{O}$-emissies uit landbouwbodems

Daarnaast kan ook de $\mathrm{CO}_{2}$-emissie door energieverbruik gedeeltelijk aan de landbouw worden toegekend, maar in de nationale rapportage wordt deze emissie onder de categorie energie gerapporteerd. In Figuur 2.1 zijn de verschillende bronnen van broeikasgassen in de landbouw schematisch weergegeven.

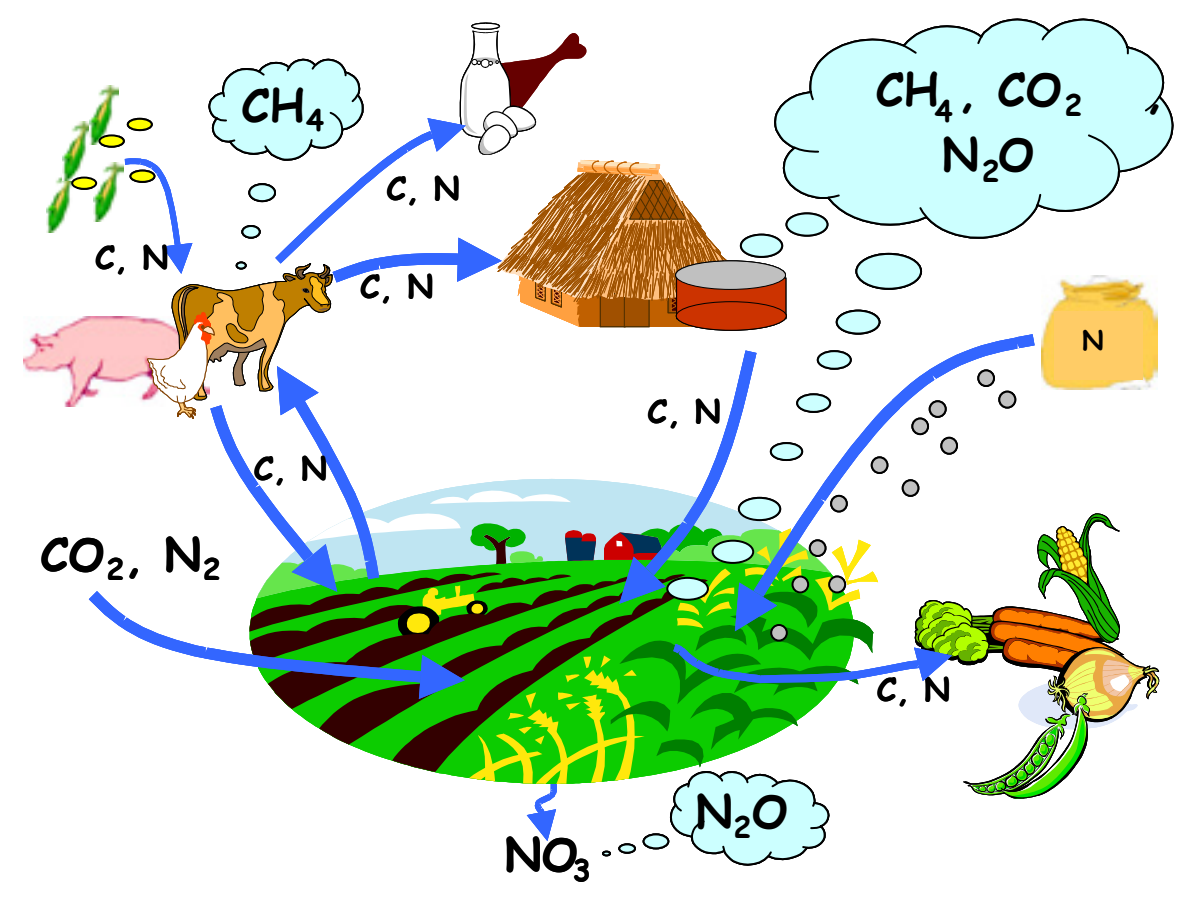

Figuur 2.1 Schematische weergave van de belangrijkste bronnen van broeikasgasemissies in de landbouw en de relatie met de verschillende stromen van stikstof en koolstof in de landbouw. 


\section{Pensfermentatie}

Methaan is een bijproduct van spijsvertering van voedsel in de magen van herkauwers. Hierbij worden koolhydraten afgebroken door micro-organismen onder anaerobe (zuurstofloze) omstandigheden. De gevormde methaan wordt uitgestoten en dit is nodig om de vertering te laten doorgaan. Zowel herkauwers (koeien, geiten, schapen) als niet-herkauwers (varkens, paarden) produceren $\mathrm{CH}_{4}$, maar herkauwers produceren aanzienlijk meer $\mathrm{CH}_{4}$ per eenheid voer dan niet-herkauwers en dit is een direct gevolg van verschillen in het verteringssysteem. Herkauwers hebben vier magen en daarmee de capaciteit om (slecht verteerbare) planten met veel cellulose zoals gras toch goed te verteren en om te zetten in melk en vlees. Dit leidt echter ook tot een forse methaanproductie. Een volwassen koe produceert gemiddeld 500 liter methaangas per dag, overeenkomend met $125 \mathrm{~kg}$ methaan per koe per jaar. Daarmee gaat circa $10 \%$ van de energie die de koe via het voer binnenkrijgt, verloren in de atmosfeer. Bij eenmagigen (niet-herkauwers) verdwijnt minder dan $1 \%$ van de energie via methaanemissies.

\section{Mestopslagen}

Emissies uit mestopslagen omvatten alle emissies uit opslagsystemen voor dierlijke mest. $\mathrm{Bij}$ behandeling en opslag van dierlijke mest wordt zowel $\mathrm{CH}_{4}$ als $\mathrm{N}_{2} \mathrm{O}$ geproduceerd. Deze emissies zijn gerelateerd aan de hoeveelheid en samenstelling van de mest en hangen verder samen met het type mestopslag en de omstandigheden tijdens de opslag. Bijvoorbeeld, onder aerobe (met zuurstof) omstandigheden tijdens de mestopslag neemt de $\mathrm{N}_{2} \mathrm{O}$-emissie in vergelijking met anaerobe (zonder zuurstof) omstandigheden toe, terwijl de $\mathrm{CH}_{4}$-emissie daalt. Een langere duur van de mestopslag en hogere temperaturen leiden echter tot een toename van de $\mathrm{CH}_{4}$-emissie. In de zomer is de methaanvorming dan ook veel groter dan in de winter. Mestopslagen dragen ongeveer $27 \%$ bij aan de totale methaanemissie uit de landbouw. Sinds het einde van de jaren tachtig is de bijdrage van mestopslagen toegenomen, omdat dierlijke mest in de winterperiode niet meer op het land wordt uitgereden en mest daardoor veel langer wordt opgeslagen.

Drie categorieën van dierlijke mestopslagen worden onderscheiden: vloeibare en vaste mestopslagsystemen en mest geproduceerd tijdens het grazen. Verse, dunne mest is zuurstofloos en bevat nog een kleine hoeveelheid gemakkelijk afbreekbare organische stof. Deze hoeveelheid komt bij koeien ruwweg overeen met $10 \%$ van de oorspronkelijke energiewaarde van het ingenomen voer. Dat betekent dat per koe, naast methaan uit pensfermentatie, nog eens 500 liter methaan per dag uit de mest kan worden geproduceerd. Deze hoeveelheid wordt onder optimale omstandigheden - zoals in vergistingsinstallaties - ook inderdaad gerealiseerd. Echter, in de praktijk is de productie van methaan uit mestopslagen een stuk lager dan in een vergister kan worden geproduceerd.

\section{Emissies uit landbouwbodems}

In Nederland worden verschillende bronnen van lachgas onderscheiden in de categorie emissies van lachgas uit landbouwbodems:

- Directe $\mathrm{N}_{2} \mathrm{O}$-emissies door de input van stikstof uit de bronnen:

- Toepassing van kunstmest

- Toedienen van dierlijke mest

- Gewasresten

- Gebruik van veenbodems (via ontwatering van veen met oxidatie of afbraak van veen tot $\mathrm{CO}_{2}$ en stikstofmineralisatie en vorming $\mathrm{N}_{2} \mathrm{O}$ tot gevolg)

- $\mathrm{N}_{2} \mathrm{O}$-emissies uit dierlijke mest en urine in de wei tijdens beweiden en grazen door vee.

- Indirecte $\mathrm{N}_{2} \mathrm{O}$-emissies door uitspoeling en oppervlakkige afstroming van stikstof en door stikstofdepositie.

Lachgas wordt in de bodem geproduceerd tijdens de microbiologische processen nitrificatie en denitrificatie. Nitrificatie is de omzetting van ammoniumstikstof $\left(\mathrm{NH}_{4}-\mathrm{N}\right)$ via een serie tussenproducten in nitriet $\left(\mathrm{NO}_{2}\right)$ en nitraat $\left(\mathrm{NO}_{3}\right)$. Lachgas ontstaat bij het nitrificatieproces als een bijproduct. Denitrificatie is de microbiologische omzetting van nitriet en nitraat via een serie tussenproducten in onschadelijk stikstofgas $\left(\mathrm{N}_{2}\right)$. Lachgas is bij zowel nitrificatie en denitrificatie proces een tussen- of bijproduct. Kunstmest en dierlijke mest zijn de belangrijkste stikstofbronnen in de landbouw en derhalve ook de belangrijkste bronnen van lachgas. De vorming en emissie van lachgas per ha landbouwgrond zijn hoog in Nederland in vergelijking tot omringende landen. Deze relatief hoge 
emissie hangt vooral samen met de hoge input van stikstof per ha en met de aanwezigheid van relatief natte gronden. Ook is de emissie van lachgas hoger als gevolg van de wettelijk verplichting om dierlijke mest bij aanwending in de bodem te injecteren om vorming van ammoniak te verminderen.

\section{Energieverbruik}

De emissie van $\mathrm{CO}_{2}$ in de landbouw door de verbranding van fossiele brandstoffen wordt in de nationale rapportage meegerekend onder de energiesector. Het grootste deel van de $\mathrm{CO}_{2}$ komt vrij bij het energieverbruik voor verwarming in de glastuinbouw en verhoging van de $\mathrm{CO}_{2}$-concentratie in kassen. Een kleiner deel van de $\mathrm{CO}_{2}$-missie is gerelateerd aan gebruik van elektriciteit en motorbrandstoffen in de landbouw. De landbouw biedt echter ook mogelijkheden voor mitigatie van broeikasgasemissies door - additionele - vastlegging van koolstof in de bodem als gevolg van gericht management, bijvoorbeeld het gebruik van groenbemesters, het niet ploegen van grasland of door behouden en conserveren van bestaande voorraden koolstof in de bodem. Dit laatste aspect is in deze studie niet meegenomen. 


\section{Methode}

\subsection{Methode voor de berekening van broeikasgasemissies}

\subsubsection{Aanpak}

De $\mathrm{N}_{2} \mathrm{O}$ - en $\mathrm{CH}_{4}$-emissies vanuit de landbouw zijn berekend met het model INITIATOR, zie Bijlage 1 voor een verdere beschrijving. Hier wordt volstaan met een korte beschrijving van de manier waarop de $\mathrm{N}_{2} \mathrm{O}$ - en $\mathrm{CH}_{4}$ - emissies zijn berekend, zie resp. paragraaf 3.1.2 en 3.1.3. Voor $\mathrm{CO}_{2}$-emissies zijn alleen de emissies door energieverbruik gerapporteerd, zie paragraaf 3.1.4. Voor de glastuinbouw zijn alleen de $\mathrm{CO}_{2}$-emissies berekend (zie paragraaf 3.1.5). $\mathrm{CO}_{2}$-emissie door landgebruik wordt buiten beschouwing gelaten.

De emissies zijn berekend per gemeente, per bedrijfstype en per bron. Voor de gemeente-indeling is de 2019-indeling gebruikt. Per 1-1-2019 zijn Geldermalsen, Lingewaal en Neerijnen samengevoegd tot de nieuwe gemeente West Betuwe. De regio-indeling is zoals in 2018 in GEA gebruikt is: Achterhoek, Arnhem, FoodValley, MARN ${ }^{1}$, Noord-Veluwe, Rivierenland en Stedendriehoek (Figuur 3.1).

De indeling van NSO-bedrijfstype in agrosectoren is vermeld in Tabel 3.1. De indeling van diercategorieën in INITIATOR staat vermeld in Bijlage 2. De emissiebronnen die worden onderscheiden, staan in Tabel 3.2.

Aan de bedrijven worden zowel de stal- en opslagemissies als de toedieningsemissies gekoppeld (onafhankelijk van het landgebruik).

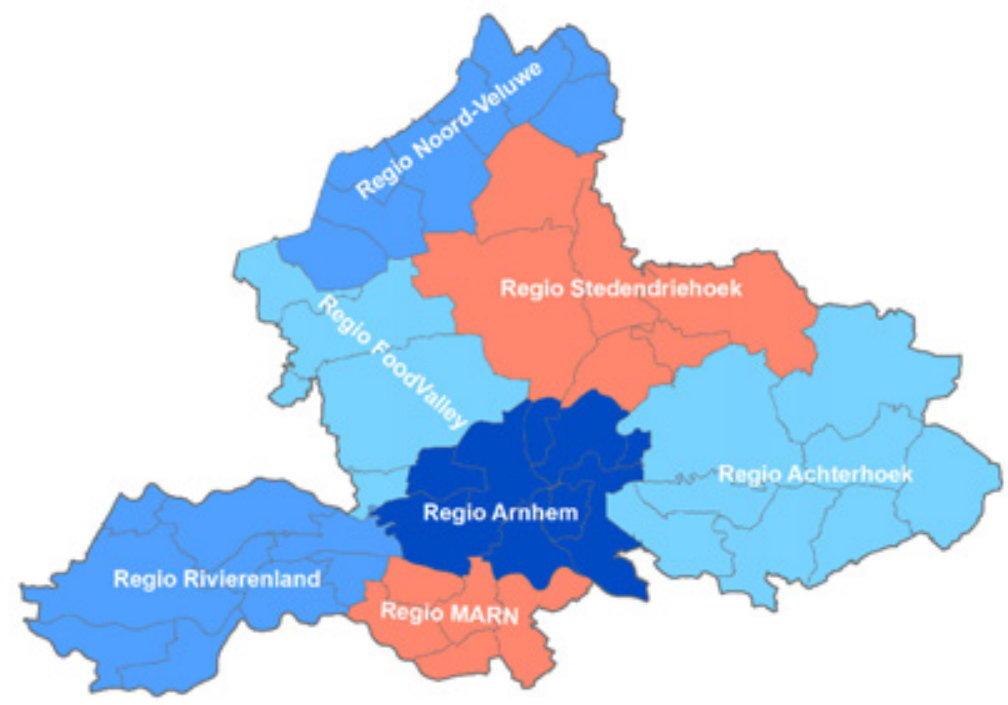

Figuur 3.1 De GEA regio-indeling in Gelderland.

\footnotetext{
1 Milieusamenwerking en Afvalverwerking Regio Nijmegen.
} 
Tabel 3.1 Indeling NSO-bedrijfstypen in sectoren.

\begin{tabular}{|c|c|}
\hline Sector & Bedrijfstype uit Landbouwtelling \\
\hline Melkveehouderij & 4500 Melkveebedrijven \\
\hline Vleeskalverhouderij & 4611 Vleeskalverenbedrijven \\
\hline \multirow[t]{3}{*}{ Varkenshouderij } & 5111 Fokzeugenbedrijven \\
\hline & 5121 Vleesvarkensbedrijven \\
\hline & 5131 Overige varkensbedrijven \\
\hline \multirow{2}{*}{ Pluimveehouderij } & 5221 Vleeskuikenbedrijven \\
\hline & 5231 Overige pluimveebedrijven \\
\hline \multirow[t]{8}{*}{ Overig veehouderij en gemengde bedrijven } & 4810 Schapenbedrijven \\
\hline & 4830 Geitenbedrijven \\
\hline & 4841 Paard- en ponybedrijven \\
\hline & 7300 Veeteeltcombinatie, vooral graasdieren \\
\hline & 7400 Veeteeltcombinatie, vooral hokdieren \\
\hline & 8300 Akkerbouw/graasdiercombinaties \\
\hline & 8400 Overige gewas/veecombinaties \\
\hline & 9000 Niet ingedeelde bedrijven \\
\hline \multirow[t]{8}{*}{ Akkerbouw, tuinbouw en blijvende teelten } & 1500 Graan-, oliezaad- en eiwitgewasbedrijven \\
\hline & 1601 Zetmeelaardappelbedrijven \\
\hline & 1602 Akkerbouwgroentebedrijven \\
\hline & 1603 Akkerbouwbedrijven vooral voedergewassen \\
\hline & 3500 Wijngaardbedrijven \\
\hline & 3610 Fruitbedrijven \\
\hline & 3699 Overige blijvendeteeltbedrijven \\
\hline & 6100 Gewascombinaties \\
\hline \multirow[t]{4}{*}{ Glastuinbouw } & 2111 Glasgroentebedrijven \\
\hline & 2121 Snijbloemenbedrijven \\
\hline & 2122 Pot- en perkplantenbedrijven \\
\hline & 2131 Overige glastuinbouwbedrijven \\
\hline
\end{tabular}

Tabel 3.2 Emissiebronnen.

\begin{tabular}{ll} 
Broeikasgas & Bronnen \\
\hline $\mathrm{N}_{2} \mathrm{O}$ & Stallen en opslagen \\
\hline & Dierlijke mesttoediening \\
\hline & Beweiding \\
\hline & Kunstmest \\
\hline & Uit- en afspoeling \\
\hline & Gewasresten \\
\hline $\mathrm{CH}_{4}$ & Mineralisatie van veengronden \\
\hline & Depositie stallen en opslagen \\
\hline $\mathrm{CO}_{2}$ & Depositie dierlijke mesttoediening \\
\hline & \\
\hline & Pensfermentatie \\
\hline & Mestmanagement \\
\hline & Elektriciteit \\
\hline & Gas \\
\hline & Brandstoffen \\
\hline
\end{tabular}


De omrekeningsfactoren van $\mathrm{N}_{2} \mathrm{O}$ en $\mathrm{CH}_{4}$ naar $\mathrm{CO}_{2}$-equivalenten (GWP) volgens IPPC (2007) zijn gebruikt (Tabel 3.3). Alhoewel dit niet de recentste GWP-factoren zijn, zijn dit wel de getallen die voor de broeikasgasemissierapportages aan de EU en UNFCCC worden gebruikt.

Tabel 3.3 Global Warming Potential (GWP): omrekening $\mathrm{N}_{2} \mathrm{O}$ en $\mathrm{CH}_{4}$ naar $\mathrm{CO}_{2}$-eq.

\begin{tabular}{ll} 
Broeikasgas (BKG) & $\mathrm{GWP}^{1)}\left(\mathrm{kg} \mathrm{CO}_{2}\right.$-eq kg BKG \\
$\mathrm{N}_{2} \mathrm{O}$ & 298 \\
$\mathrm{CH}_{4}$ & 25 \\
\hline
\end{tabular}

1) Gebaseerd op AR4 IPCC (IPCC, 2007).

\subsubsection{Lachgasemissie}

Voor de berekeningsmethodiek volgen we de NEMA/NIR-methodiek zoals beschreven in Vonk et al. (2018). De met INITIATOR berekende $\mathrm{N}$-fluxen worden vermenigvuldigd met $\mathrm{N}_{2} \mathrm{O}$-emissiefactoren (zie Tabel 3.4 en Tabel 3.5). De $\mathrm{N}_{2} \mathrm{O}$-emissie door mineralisatie van veen is toegekend aan de melkveehouderijsector.

De $\mathrm{N}_{2} \mathrm{O}$-emissie door gewasresten is volledig gesynchroniseerd met NEMA. NEMA gebruikt N-toevoer in gewasresten voor ca. 50 gewassen (Van Bruggen et al., 2018). Deze gewassen zijn in INITIATOR gekoppeld aan de ruim 300 gewassen uit de Basisregistratie Gewaspercelen voor het jaar 2016 (BRP; $\mathrm{RVO}^{2}$ ).

Tabel 3.4 Berekeningsmethode $\mathrm{N}_{2} \mathrm{O}$-emissies.

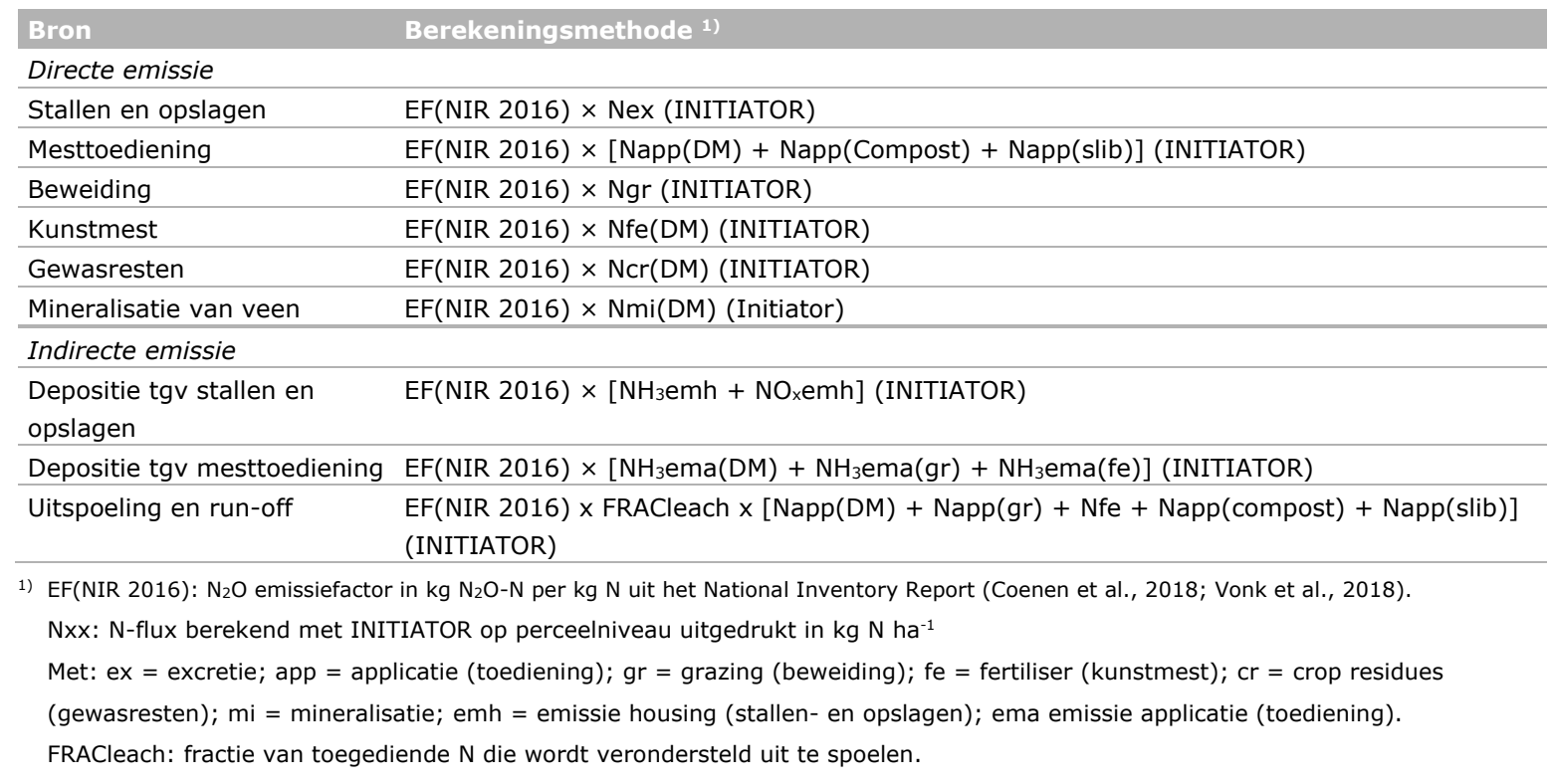

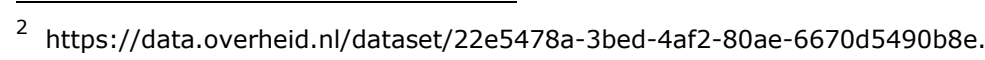


Tabel 3.5 Gebruikte $\mathrm{N}_{2} \mathrm{O}$-emissiefactoren.

\begin{tabular}{|c|c|c|}
\hline \multirow[t]{2}{*}{ Type input } & \multirow[t]{2}{*}{ Onderverdeling } & $\mathrm{frN}_{2} \mathrm{O}_{\mathrm{em}}(\%)$ \\
\hline & & NIR2016/2018 ${ }^{1)}$ \\
\hline \multirow[t]{2}{*}{ Excretie (stallen) } & Drijfmest & 0,2 \\
\hline & Vaste mest & 0,5 ( 0,1 voor pluimveemest) \\
\hline \multirow[t]{2}{*}{ Dierlijke mest toediening } & Bovengronds toedienen & 0,4 \\
\hline & Emissiearm toedienen & 0,9 \\
\hline Begrazing & Alle diersoorten & 3,3 \\
\hline Gewasresten & - & 1,0 \\
\hline \multirow[t]{2}{*}{ Zuiveringsslib ${ }^{3)}$} & Bovengronds toedienen & 0,4 \\
\hline & Emissiearm toedienen & 0,9 \\
\hline Compost & & 0,4 \\
\hline Ontwatering veengronden & & 2,0 \\
\hline \multicolumn{2}{|l|}{ FRAC $_{\text {leach }}{ }^{4)}$} & $13 \mathrm{~kg} \mathrm{~N}$ per $\mathrm{kg} \mathrm{N}$ toegediend \\
\hline \multicolumn{3}{|l|}{ 1) Zie Vonk et al. (2018). } \\
\hline \multicolumn{3}{|c|}{ 2) Emissiefactor gebaseerd op gewogen gemiddelde van de in Nederland toegepaste N-kunstmestsoorten. } \\
\hline \multicolumn{3}{|c|}{ 3) Voor zuiveringsslib zijn de emissiefactoren van dierlijke mesttoediening gebruikt. } \\
\hline \multicolumn{3}{|c|}{ 4) Betreft fractie van toegediende $\mathrm{N}$. } \\
\hline
\end{tabular}

\subsubsection{Methaanemissie}

Fermentatieprocessen in de pens van vee, met name rundvee (pensfermentatie), en emissies uit dierlijke mest (mestmanagement) zijn de belangrijkste bronnen van $\mathrm{CH}_{4}$. Deze twee bronnen worden daarom ook onderscheiden in de emissierapportages.

De $\mathrm{CH}_{4}$-emissie door pensfermentatie en mestmanagement zijn in INITIATOR, conform NIR2016, berekend door vermenigvuldiging van een emissiefactor voor $\mathrm{CH}_{4}$ per diersoort met het aantal dieren per onderscheiden bedrijf (ongeacht of ze op stal of in de weide staan), waarbij de dieraantallen uit GIABplus (Van Os et al., 2016) zijn gebruikt en de emissiefactoren uit Van Bruggen et al. (2017). Het gaat hierbij om de emissies per dier uit pensfermentatie (Tabel 3.6) en mestmanagement (Tabel 3.7).

Tabel 3.6 Emissiefactoren voor methaan uit pens- en darmfermentatie ( $\mathrm{kg} \mathrm{CH}_{4} /$ dier/jaar).

\begin{tabular}{|c|c|c|}
\hline & Diercategorie & 2016 \\
\hline a1 & Melk- en kalfkoeien - Noordwest-Nederland & 130,9 \\
\hline a1 & Melk- en kalfkoeien - Zuidoost-Nederland & 128,2 \\
\hline a4 & Witvleeskalveren & 8,9 \\
\hline a4 & Rosévleeskalveren & 31,9 \\
\hline a6 & Vleesstieren en overig vleesvee van circa 8 tot 24 maanden (roodvleesproductie) & 65,6 \\
\hline a3 & Vrouwelijk jongvee $<2 \mathrm{jr}$ & 45,9 \\
\hline $\mathrm{d} 12$ & Kraamzeugen (incl. biggen tot spenen) & 1,5 \\
\hline d13 & Guste en dragende zeugen & 1,5 \\
\hline $\mathrm{d} 2$ & Dekberen, $>=7$ maanden & 1,5 \\
\hline d3 & Vleesvarkens, opfokberen en -zeugen & 1,5 \\
\hline e1 & Opfokhennen en hanen van legras $<18$ weken & 0 \\
\hline e2 & Legkippen & 0 \\
\hline $\mathrm{g} 12$ & Vleeseenden en ouderdieren van vleeseenden & 0 \\
\hline f4 & Vleeskalkoenen & 0 \\
\hline b1 & Schapen & 8,0 \\
\hline $\mathrm{c} 1$ & Geiten & 5,0 \\
\hline $\mathrm{k} 12$ & Paarden & 18,0 \\
\hline k34 & Pony's & 18,0 \\
\hline i1 & Konijnen (alle) & 0 \\
\hline h1 & Nertsen (teven) & 0 \\
\hline
\end{tabular}


Tabel 3.7 Emissiefactoren voor methaan uit mest voor diercategorieën waarvoor een Tier 2berekening is toegepast ( $\mathrm{kg} \mathrm{CH} \mathrm{CH}_{4} /$ dier/jaar).

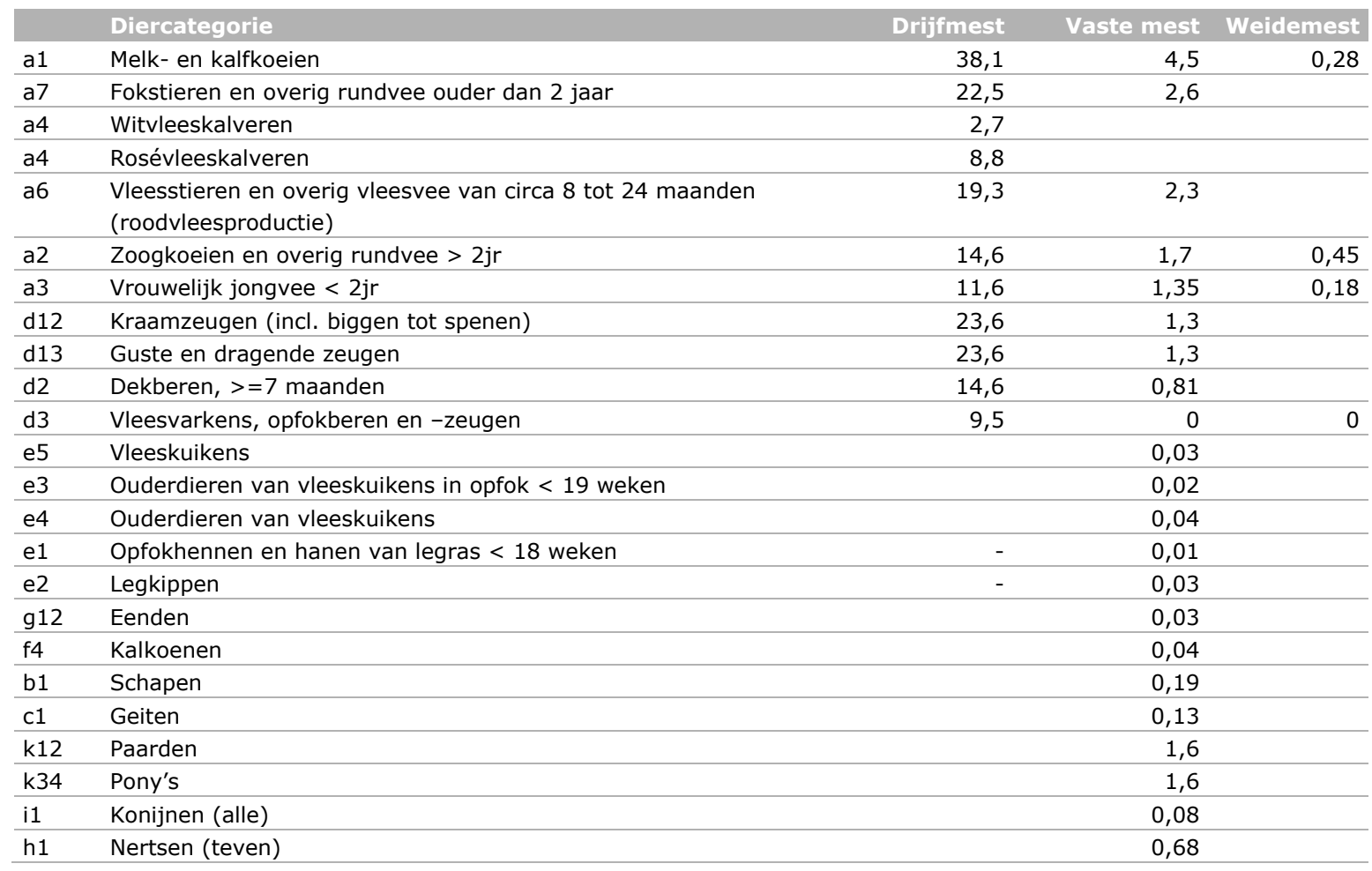

Bron: Van Bruggen et al. (2017).

\subsection{4 $\mathrm{CO}_{2}$-emissie door energieverbruik}

Voor $\mathrm{CO}_{2}$-emissies door energieverbruik is een onderscheid gemaakt tussen de glastuinbouw en de overige landbouwsectoren. In deze sectie staat de aanpak voor de overige landbouwsectoren beschreven en in sectie 3.1.5 de aanpak voor de glastuinbouw.

Het CBS is sinds 2013 gestopt met het leveren van statistieken over energieverbruik per landbouwsector. Hierdoor was een andere aanpak nodig vergeleken met de nulmetingstudie uit 2009. Via collega's van Wageningen Economic Research is nu gebruikgemaakt van gegevens uit het Bedrijveninformatienet (BIN) van Wageningen Economic Research. Uit deze database is het landelijk gemiddelde gebruik van elektriciteit, gas en diesel per bedrijfstype bepaald en gekoppeld aan de verschillende bedrijfstypen zoals gebruikt in deze studie. In Tabel 3.8 staat per sector het energieverbruik per bedrijf per energiedrager.

Tabel 3.8 Energieverbruik per bedrijf in 2017 naar sector en naar energiedrager.

\begin{tabular}{|c|c|c|c|}
\hline \multirow[t]{2}{*}{ Sectoren } & \multicolumn{3}{|c|}{ Energieverbruik per bedrijf } \\
\hline & elektriciteit (kWh) & gas $\left(m^{3}\right)$ & diesel (I) \\
\hline Melkveehouderij & 45.191 & 1.340 & 8.543 \\
\hline vleesveehouderij = ov. graasdieren (incl. geitenbedr.) & 15.520 & 701 & 3.507 \\
\hline waarvan geitenbedrijven & 61.720 & 2.197 & 8.398 \\
\hline Varkenshouderij & 140.082 & 10.433 & 2.678 \\
\hline Vleesvarkens & 89.238 & 2.838 & 1.870 \\
\hline overig/gemengd & 226.617 & 19.509 & 5.516 \\
\hline Pluimveehouderij & 122.306 & 12.436 & 4.497 \\
\hline Leghennen & 131.669 & 2.214 & 3.570 \\
\hline Vleeskuikens & 111.753 & 23.959 & 5.543 \\
\hline
\end{tabular}

1) Type vleesvee te beperkt aantal bedrijven; zit in ov. graasdieren (= so type $=4$ minus melkvee en vleeskalveren), maar inclusief geiten die ook apart is opgenomen.

Bron: Bedrijveninformatienet van Wageningen Economic Research. 
Bij deze werkwijze dient de kanttekening gemaakt te worden dat het hier het voor Nederland gemiddelde verbruik per sector betreft, waarbij de aanname is dat het verbruik in Gelderland niet afwijkt van het gemiddelde in Nederland. Die aanname is discutabel, want er zijn verschillende redenen denkbaar waarom die aanname niet klopt, zoals gemiddeld andere grondsoort, ander bouwplan/gewassenkeuze, andere omvang van bedrijven, die alle invloed kunnen hebben op de efficiëntie van energieverbruik en afwijkende veebezetting (intensiteit). De uiteindelijke resultaten zijn hierdoor mogelijk niet helemaal representatief, maar de best mogelijke schatting binnen het budget en tijdsduur van dit project.

De indeling in sectoren komt niet helemaal overeen met de in de rest van de studie gehanteerde indeling. De varkenshouderijsector is onderverdeeld in zeugen, vleesvarkens en varkensoverig/gemengd, en de pluimveehouderijsector is onderverdeeld in leghennen en vleeskuikens. Het aantal BIN-bedrijven in enkele sectoren is te beperkt om energieverbruikswaarden te kunnen geven. Daarom wordt voor de vleesveehouderij en voor overige veehouderij het energieverbruik van overige graasdieren gebruikt; voor pluimvee-overig/gemengd wordt pluimveehouderij genomen. Gemengde bedrijven is een aparte categorie. Akkerbouw, tuinbouw en blijvende teelten is het naar aantal bedrijven gewogen gemiddelde van bedrijven in deze sectoren.

Het energieverbruik is omgerekend naar $\mathrm{CO}_{2}$-equivalenten op basis van emissiefactoren uit de Klimaatmonitor (https://klimaatmonitor.databank.nl/Jive), zie Tabel 3.9.

Tabel 3.9 Emissiefactoren energiedragers (Klimaatmonitor).

\begin{tabular}{llll} 
Energiedrager & Eenheid & Emissie factor in $\mathrm{kg} \mathrm{CO}$-eq/eenheid & Jaar \\
Stroom & $\mathrm{kWh}$ & 0,49 & 2016 \\
\hline Diesel & $\mathrm{L}$ & 2,6 & 2017 \\
\hline Aardgas & $\mathrm{m}^{3}$ & 1,79 & 2017 \\
\hline
\end{tabular}

\subsubsection{Broeikasgasemissies glastuinbouw}

Van de $\mathrm{CO}_{2}$-emissie door energieverbruik in glastuinbouw is een grove schatting gemaakt op gemeenteniveau door gebruik te maken van de nationale gegevens uit De Energiemonitor Nederlandse glastuinbouw 2017 (Van der Velden en Smit, 2018) en deze per hectare neer te schalen per gemeente. Aangenomen is dat het verbruik in Gelderland niet afwijkt van het landelijk gemiddelde.

In Figuur 3.2 is het energieverbruik in de glastuinbouw op basis van de energiemonitor weergegeven. $\mathrm{Er}$ is geen onderscheid gemaakt naar de verschillende energiedragers, aangezien dat nogal complex is voor de glastuinbouw, die door warmtekrachtkoppeling naast inkoop ook verkoop van elektriciteit heeft. Er is uitgegaan van de in Bijlage 2 van het energiemonitorrapport vermelde totale broeikasgasemissie van 5,9 Mton $\mathrm{CO}_{2}$-eq. Het totale areaal glastuinbouw voor agrarisch gebruik in 2017 is 9080 hectare (CBS). Dit leidt tot een emissiefactor van 650 ton $\mathrm{CO}_{2}$-eq/ha. Op basis van deze landelijk gemiddelde emissiefactor en het areaal glas per gemeente (bron $\mathrm{CBS}^{3}$ ) is voor de provincie Gelderland per gemeente de $\mathrm{CO}_{2}$-emissie t.g.v. energieverbruik in de glastuinbouw berekend.

\footnotetext{
3 https://statline.cbs.nl/Statweb/selection/?DM $=$ SLNL\&PA=80781NED\&VW=T
} 


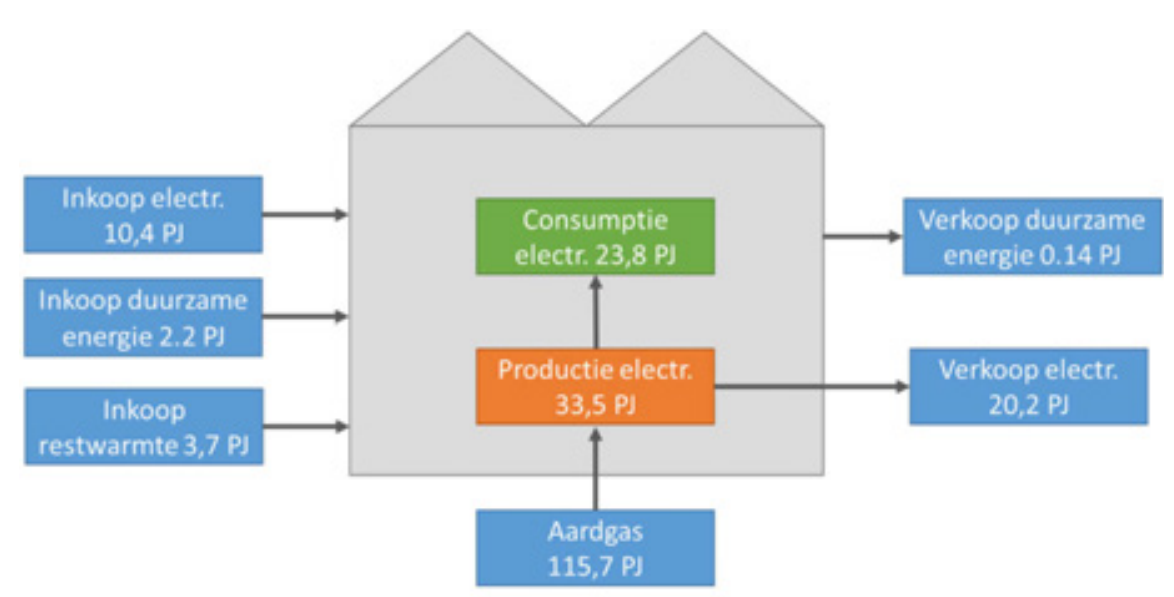

Figuur 3.2 Schema energiegebruik in de glastuinbouw in Nederland. Bron: De Energiemonitor Nederlandse glastuinbouw 2017.

De $\mathrm{N}_{2} \mathrm{O}$ - en $\mathrm{CH}_{4}$-emissies zijn met de standaard INITIATOR/NEMA-methode bepaald voor de glastuinbouwbedrijven in GIAB. Hiervoor zijn de NSO-typen gebruikt zoals vermeld in Tabel 3.1. Het gaat hierbij om 12.184 ha voor Nederland, wat dus ca. 3.000 ha (12.184 minus 9.079) nietproductieglastuinbouw-areaal omvat. Voor deze hectares is de standaard INITIATOR/NEMA-methode toegepast, wat inhoudt dat alleen emissies van mestproductie, mesttoediening, gewasresten etc. zijn berekend op basis van (i) het aantal dieren per bedrijf en (ii) het aantal ha bouwland en grasland per bedrijf. Het gaat hierbij dus om de landbouwactiviteiten van het als glastuinbouw geïdentificeerde bedrijf die naast de glastuinbouwactiviteiten worden uitgevoerd. Kortom, het zijn niet de $\mathrm{N}_{2} \mathrm{O}-\mathrm{en}^{\mathrm{CH}_{4}-}$ emissies uit de kassen, maar de emissies gerelateerd aan de landbouwactiviteiten buiten de glastuinbouw bij deze bedrijven. 


\section{Broeikasgasemissies uit de landbouw in 2016}

\subsection{Broeikasgasemissies per sector}

In Tabel 4.1 staan de berekende broeikasgasemissies in 2016/2017 voor de verschillende agrosectoren. De totale broeikasgasemissie uit de landbouw in Gelderland bedraagt 3517 kton $\mathrm{CO}_{2}$ equivalenten. Dat is $13,6 \%$ van de berekende landelijke emissies uit de landbouw. De verdeling over de verschillende broeikasgassen is als volgt: 2,1 Mton $\mathrm{CO}_{2}$-equivalenten methaan, 0,7 Mton $\mathrm{CO}_{2}$ equivalenten lachgas en 0,7 Mton $\mathrm{CO}_{2}$. De melkveehouderij heeft het grootste aandeel in de Gelderse emissie, namelijk 1.770 kton $\mathrm{CO}_{2}$-equivalenten. Dat is de helft van de totale Gelderse broeikasgasemissie uit de landbouw. De sector overige veehouderij en gemengde bedrijven en de varkenshouderijsector komen op de tweede en derde plaats met respectievelijk $12,8 \%$ en $10,9 \%$ van de Gelderse emissie. Ook voor Nederland staat de melkveehouderij op één wat betreft de broeikasgasemissies uit de landbouw. De tweede grootste is nationaal echter de glastuinbouw met $22,5 \%$, gevolgd door de varkenshouderij op drie met $9,6 \%$.

De bijdrage van de pluimveehouderij is zeer beperkt, echter de grootste emissies uit deze sector zijn gerelateerd aan de productie van voer en aangezien het merendeel van het voer wordt geïmporteerd, komen deze emissies niet tot uitdrukking in deze rapportage. Ketenanalyses laten echter zien dat de voerketen een grote emissiebron kan zijn, met name als er ook voerproducten gerelateerd aan ontbossing gebruikt worden, zoals soja. Dit is met name voor de pluimvee en varkenshouderij een grote bijdrage aan de footprint, maar in de rapportagesystematiek wordt deze niet aan Nederland toegerekend.

De bijdrage van Gelderland aan de landelijke emissie uit de landbouw is bij de veehouderij groter dan gemiddeld en het grootst voor de vleeskalverhouderij, namelijk 42,6\%. De akker- en tuinbouw en de glastuinbouw dragen minder dan gemiddeld bij aan de landelijke emissie (respectievelijk 8,2\% en $5,1 \%)$.

In Bijlage 4 staan de broeikasgasemissies per GEA-regio, per gemeente en per sector.

Tabel 4.10 Broeikasgasemissie ( $k$ ton $\mathrm{CO}_{2}$-equivalent) per agrosector voor Gelderland en Nederland in 2016/2017.

\begin{tabular}{|c|c|c|c|c|c|}
\hline \multirow[t]{2}{*}{ Agrosector } & \multirow[t]{2}{*}{ Gelderland } & \multirow[t]{2}{*}{ Nederland } & \multicolumn{2}{|c|}{ Aandeel agrosector (\%) } & \multirow[t]{2}{*}{ Aandeel Gelderland (\%) } \\
\hline & & & Gelderland & Nederland & \\
\hline Melkveehouderij & 1770 & 12105 & 50,3 & 47,0 & 14,6 \\
\hline Vleesveehouderij & 189 & 786 & 5,4 & 3,0 & 24,1 \\
\hline Vleeskalverhouderij & 245 & 576 & 7,0 & 2,2 & 42,6 \\
\hline Varkenshouderij & 385 & 2474 & 10,9 & 9,6 & 15,6 \\
\hline Pluimveehouderij & 66 & 311 & 1,9 & 1,2 & 21,1 \\
\hline $\begin{array}{l}\text { Overig veehouderij en } \\
\text { gemengde bedrijven }\end{array}$ & 449 & 2295 & 12,8 & 8,9 & 19,6 \\
\hline $\begin{array}{l}\text { Akkerbouw, tuinbouw en } \\
\text { blijvende teelten }\end{array}$ & 118 & 1441 & 3,4 & 5,6 & 8,2 \\
\hline Glastuinbouw & 294 & 5792 & 8,4 & 22,5 & 5,1 \\
\hline Totaal & 3517 & 25781 & 100,0 & 100,0 & 13,6 \\
\hline
\end{tabular}




\subsection{Broeikasgasemissies per bron}

In Bijlage 3 staan de berekende broeikasgasemissies voor de verschillende agrosectoren opgesplitst naar de verschillende bronnen van broeikasgasemissies weergegeven in kton $\mathrm{N}_{2} \mathrm{O}$ of $\mathrm{CH}_{4}$ en in kton $\mathrm{CO}_{2}$-equivalenten. De grootste bron is methaanemissie door pensfermentatie (40\%). Methaanemissie door mestmanagement, totale $\mathrm{N}_{2} \mathrm{O}$-emissie en totale energie gerelateerde $\mathrm{CO}_{2}$-emissies zijn verantwoordelijk voor steeds ca. $20 \%$ van de totale Gelderse emissie. In Figuur 4.1 zijn per sector de verschillende bronnen van broeikasgasemissies aangegeven. In de melkveehouderij is de methaanemissie door pensfermentatie de grootste bron (955 kton $\mathrm{CO}_{2}$-eq, 54\%), gevolgd door de methaanemissie door mestmanagement (260 kton $\mathrm{CO}_{2}-\mathrm{eq}, 15 \%$ ). $\mathrm{Bij}$ de varkenshouderij is methaanemissie door mestmanagement de grootste bron (246 kton $\mathrm{CO}_{2}$-eq, 64\%). Bij de sector overige veehouderij en gemengde bedrijven zijn drie grote bronnen: pensfermentatie, mestmanagement en energieverbruik (resp. 144, 84 en 133 kton $\mathrm{CO}_{2}$-eq). In de glastuinbouw is 294 kton $\mathrm{CO}_{2}$-eq $\mathrm{CO}_{2}$-emissie door energieverbruik.

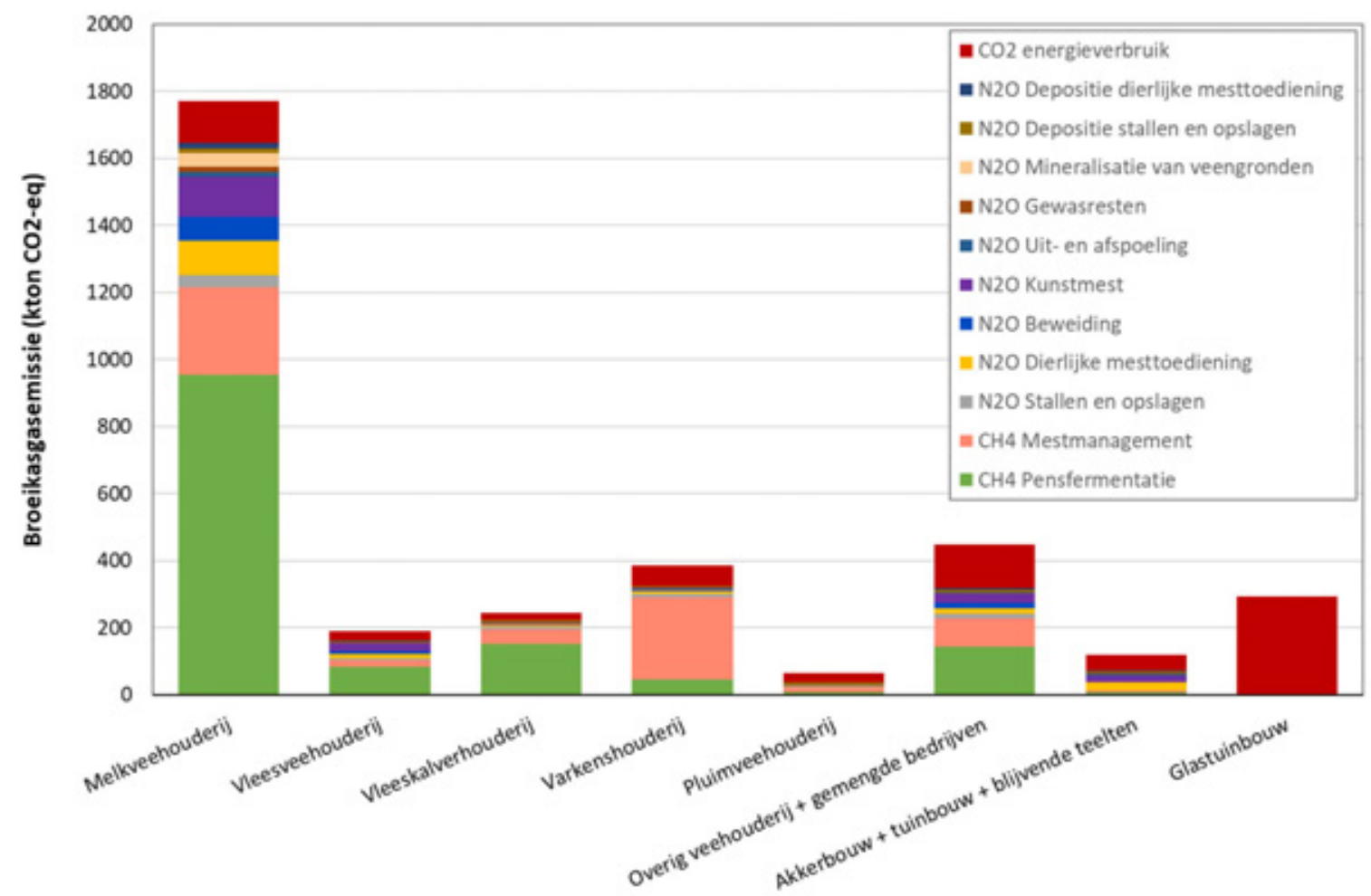

Figuur 4.3 Broeikasgasemissie in Gelderland per agrosector opgesplitst in verschillende broeikasgasemissiebronnen voor het jaar 2016/2017.

De broeikasgasemissies per bron voor Gelderland en Nederland staan in Tabel 4.2, deze cijfers zijn via dezelfde methodiek berekend. Te zien is dat de verdeling over de bronnen in Gelderland min of meer hetzelfde is als in Nederland. Het aandeel van de verschillende bronnen in Gelderland van Nederland ligt tussen 10 à $20 \%$. 
Tabel 4.11 Broeikasgasemissie (kton $\mathrm{CO}_{2}$-equivalent) per bron voor Gelderland en Nederland in $2016 / 2017$.

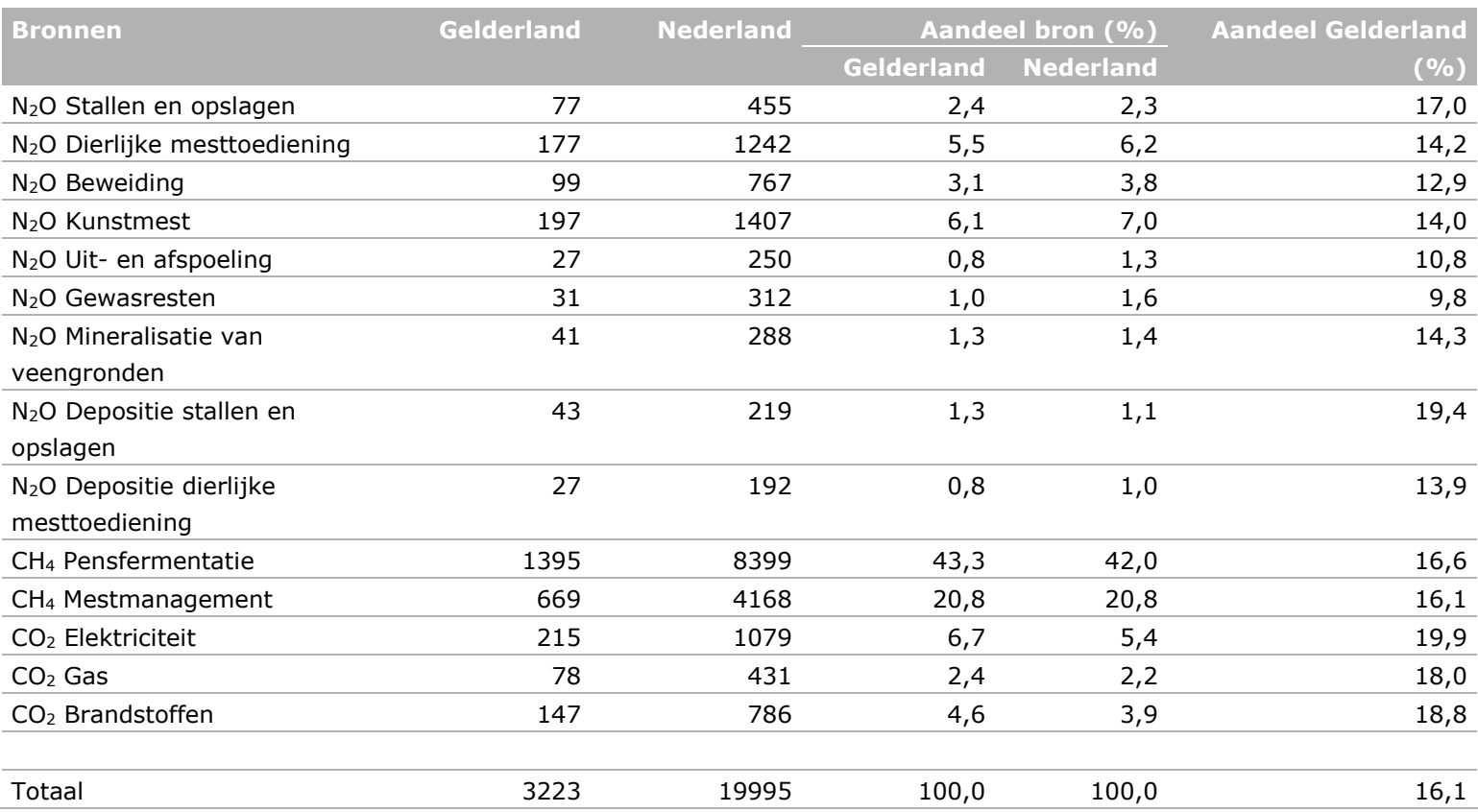

\subsection{Ruimtelijke verdeling van broeikasgasemissies}

De emissie van broeikasgassen is niet gelijk verdeeld over Gelderland. In Figuur 4.2 is de ruimtelijke verdeling van de emissies per gemeente te zien, uitgedrukt in emissie per hectare landbouwgrond. De hoogste emissies vinden plaats in de Gelderse Vallei (Harderwijk tot Ede) en in Zaltbommel en de Lingewaard. De laagste in de strook Buren tot Arnhem en in Nijmegen en Doesburg. Figuur 4.3 geeft de ruimtelijke verdeling per agrosector weer. Broeikasgasemissies door de melkveehouderij komen met name voor in de Achterhoek. De vleeskalverhouderij en de pluimveehouderij zijn geconcentreerd in de Gelderse Vallei. Emissie uit de varkenshouderij is behalve in de Gelderse Vallei ook duidelijk aanwezig in de Achterhoek en de strook West Maas en Waal tot Nijmegen. De $\mathrm{CO}_{2}$-emissie door energiegebruik in de glastuinbouw komt vooral voor in het gebied rond Zaltbommel en rond de Lingewaard.

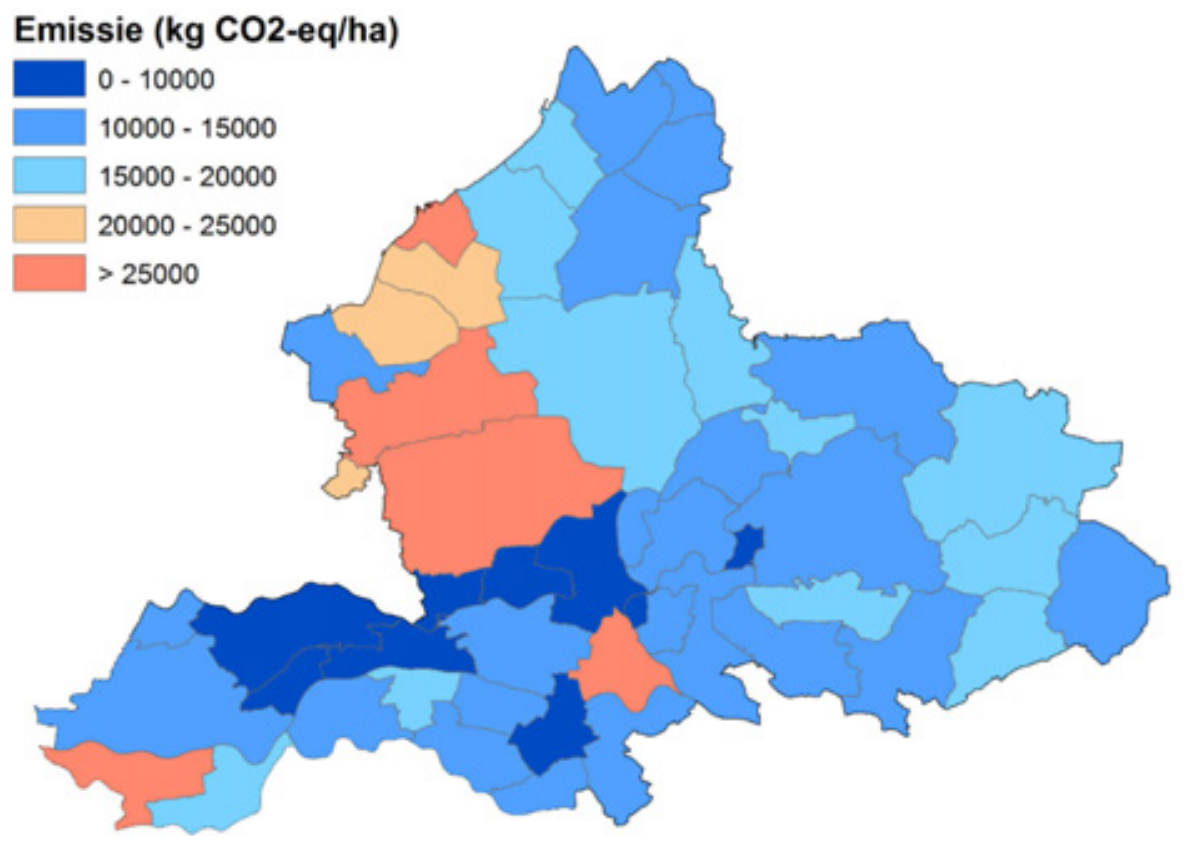

Figuur 4.4 Broeikasgasemissie van de Gelderse landbouw per gemeente ( $k g \mathrm{CO}_{2}$-eq ha-1 $\mathrm{jr}^{-1}$ ). 

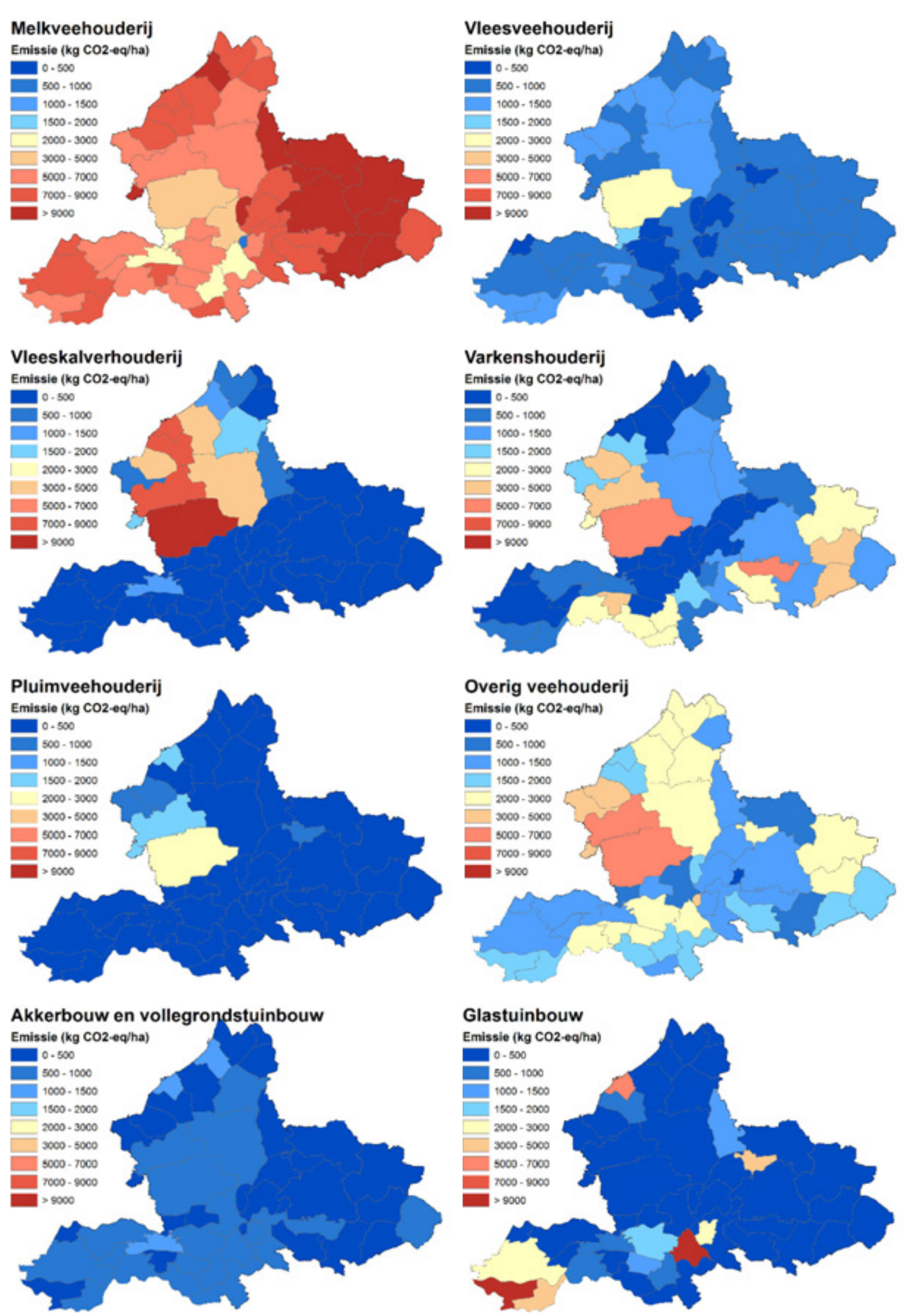

Figuur 4.5 Broeikasgasemissie van de verschillende agrosectoren per gemeente in Gelderland (kg $\mathrm{CO}_{2}$-eq $\mathrm{ha}^{-1} \mathrm{jr}^{-1}$ ). 


\section{$5 \quad$ Vergelijking broeikasgasemissies 2005 en 2016}

Voor de vergelijking van de broeikasgasemissies van 2016/2017 met de nulmeting van 2005 (Lesschen et al., 2009) is het van belang te weten dat er verschillen zijn in de gebruikte methodiek en de basisdata, waardoor een gedetailleerde vergelijking niet direct mogelijk is. Hiervoor zou ook de emissie met de huidige methodiek voor 2005 berekend moeten worden, maar dat was geen onderdeel van deze opdracht. De vergelijking hieronder is dan ook een vergelijking op hoofdlijnen.

De methodiek verschilt in de gebruikte modellen, MITERRA voor 2005 en INITIATOR voor 2016, en de onderliggende berekeningen. Een van de grootste verschillen is dat INITIATOR data op bedrijfsniveau gebruikt, terwijl MITERRA rekende met geaggregeerde data op gemeenteniveau. Hierdoor is met INITIATOR een betere toewijzing van de bodemgerelateerde emissies aan de verschillende bedrijfstypen verkregen, terwijl in de studie van Lesschen et al. (2009) hier nog ruwe aannames voor gemaakt zijn.

De broeikasgasemissie door energieverbruik is voor 2005 afgeleid uit nationale CBS-gegevens per bedrijfstype, terwijl dit voor 2016 is berekend op basis van nationaal gemiddeld energieverbruik per bedrijf per agrosector uit het BIN en voor de glastuinbouw op basis van de energiemonitor glastuinbouw. Vaak zijn indelingen in diercategorieën, bedrijfstypen, agrosectoren van datasets veranderd, zodat er aanpassingen in de clustering nodig waren. Daarin is verschil mogelijk, wat doorwerkt in de berekende emissies. Ook kunnen de gebruikte emissiefactoren verschillen, aangezien deze jaarlijks aangepast kunnen worden door veranderingen in de onderliggende data. Zo worden de methaanemissiefactoren jaarlijks bepaald op basis van o.a. de voerstatistieken, die kunnen leiden tot verschillen in verteerbaarheid. De $\mathrm{N}_{2} \mathrm{O}$-emissiefactoren die gebruikt zijn voor de berekeningen voor 2005, zijn gebaseerd op de IPCC 2006 richtlijnen, deze verschillen met de $\mathrm{N}_{2} \mathrm{O}$-emissiefactoren volgens NIR 2016/2018 die gebruikt zijn voor de berekeningen voor 2016. Ook de emissiefactor van elektriciteit verschilt voor 2005 en 2016, namelijk respectievelijk 0,60 kg CO$/ 2$ kh en 0,49 kg CO $2 / k W h$. De omrekeningsfactoren van $\mathrm{N}_{2} \mathrm{O}$ en $\mathrm{CH}_{4}$ naar $\mathrm{CO}_{2}$-equivalenten waren bij beide studies hetzelfde.

De belangrijkste basisdata zijn de dieraantallen. Het aantal dieren is sterk bepalend voor de omvang van de emissies. Het MITERRA-model gebruikt de dieraantallen op gemeenteniveau uit de regionale landbouwtelling van het CBS. Het model INITIATOR gebruikt de dieraantallen uit de landbouwtelling op bedrijfsniveau (dieraantallen en locatiegegevens zoals die in het GIABplus-systeem binnen WENR zijn opgeslagen). Dit kan verschil opleveren wanneer een nevenvestiging in een andere gemeente ligt. In Tabel 5.1 staan de dieraantallen per diertype en per agrosector in 2005 en 2016 . Het aantal stuks melkvee, vleeskalveren en overig vee is met 15 à $19 \%$ toegenomen. Varkens en pluimvee zijn met respectievelijk $18 \%$ en $9 \%$ afgenomen. Het dieraantal vleesvee is in $201654 \%$ lager dan in 2005.

In Tabel 5.2 zijn de broeikasgasemissies per sector in 2005 en 2016 weergegeven. De broeikasgasemissie uit de melkveehouderij is licht toegenomen. Bij de vleesveehouderij, de varkenshouderij en de pluimveehouderij is de emissie gedaald. Bij de pluimveehouderij is de daling van de emissie (74\%) veel sterker dan de daling in het dieraantal (9\%). In 2005 vormt de $\mathrm{N}_{2} \mathrm{O}$-emissie uit stallen en opslag het merendeel van de emissies in de pluimveehouderij (zie Figuur 4.1 van de nulmeting), maar in 2016 is deze veel kleiner door het gebruik van een verbeterde, lagere emissiefactor. De emissie van de vleeskalverhouderij is met $67 \%$ toegenomen, terwijl het dieraantal maar $17 \%$ toenam. Dit verschil is deels te verklaren door toewijzing van een deel van de bodememissies aan deze sector, aangezien in de studie van Lesschen et al. (2009) geen bedrijfsinformatie gebruikt is en de bodememissies zijn toegerekend aan de melkveehouderij en akkerbouw.

De sector overige veehouderij en gemengde bedrijven laat een groot verschil in emissie zien tussen 2005 en 2016. De belangrijkste reden hiervoor is dat deze sector een restpost is bij het indelen van dier- en bedrijfstypen in sectoren, zodat overige veebedrijfstypen en gemengde bedrijfstypen onder deze categorie vallen, terwijl in de studie van Lesschen et al. (2009) voor 2005 alleen de emissies 
gerelateerd aan de overige diercategorieën onder deze klasse zijn meegenomen. Daarnaast is ook het aantal geiten in de provincie Gelderland verdubbeld tussen 2005 en 2016, wat bijdraagt aan de toename van de emissies.

De broeikasgasemissie in de akkerbouw, tuinbouw en blijvende teelten in 2016 is $22 \%$ lager dan de emissie van de akkerbouw in 2005. De emissie door energiegebruik in de glastuinbouw in 2016 is $43 \%$ lager dan in 2005. Dit is voor het merendeel te verklaren door een afname in het areaal glastuinbouw, van 730 ha in 2005 naar 452 ha in 2017 . Wel dient opgemerkt te worden dat de methodiek voor glastuinbouw in beide jaren verschillend was en gebaseerd is op nationale gegevens.

Tabel 5.12 Dieraantallen per agrosector voor Gelderland in 2005 en 2016.

\begin{tabular}{lrrr} 
Diertype & $2005{ }^{1)}$ & $\left.2016^{2}\right)$ & $2016 / 2005(\%)$ \\
Melkvee & 414.598 & 475.704 & 115 \\
\hline Vleesvee & 83.464 & 38.003 & 46.746 \\
\hline Vleeskalveren & 369.334 & 117 \\
\hline Varkens & 1.295 .661 & 1.065 .017 & 16.285 .738 \\
\hline Pluimvee & 17.938 .556 & 329.489 & 119 \\
\hline Overig vee & 277.133 & 115.923 & 195 \\
\hline \multicolumn{1}{c}{ warvan geiten }
\end{tabular}

1) Bron 2005: CBS landbouwtelling op gemeenteniveau.

2) Bron 2016: GIABplus o.b.v. CBS Landbouwtelling op bedrijfsniveau.

Tabel 5.13 Broeikasgasemissie per agrosector voor Gelderland in 2005 en 2016.

\begin{tabular}{|c|c|c|c|}
\hline Agrosector & 2005 & 2016 & $2016 / 2005(\%)$ \\
\hline Melkveehouderij & 1700 & 1770 & 104 \\
\hline Vleesveehouderij & 287 & 189 & 66 \\
\hline Varkenshouderij & 449 & 385 & 86 \\
\hline Pluimveehouderij & 249 & 66 & 26 \\
\hline Glastuinbouw & 516 & 294 & 57 \\
\hline Totaal & 3547 & 3517 & 99 \\
\hline
\end{tabular}




\section{Conclusies en aanbevelingen}

De totale broeikasgasemissie uit de landbouw in Gelderland bedraagt 3,5 Mton $\mathrm{CO}_{2}$-equivalenten. Dat is $13,6 \%$ van de berekende landelijke emissies uit de landbouw. De verdeling over de verschillende broeikasgassen is als volgt: 2,1 Mton $\mathrm{CO}_{2}$-equivalenten methaan, 0,7 Mton $\mathrm{CO}_{2}$-equivalenten lachgas en $0,7 \mathrm{Mton} \mathrm{CO}_{2}$. De helft van de emissie komt voor rekening van de melkveehouderij, met name door methaanemissie door pensfermentatie. De sector overige veehouderij en gemengde bedrijven zorgt voor $13 \%$ van de totale Gelderse emissie door pensfermentatie, mestmanagement en energieverbruik. Volgens de GEA-monitoring was de totale $\mathrm{CO}_{2}$-emissie door energiegebruik in Gelderland, inclusief energiegebruik uit landbouw, 15 Mton $\mathrm{CO}_{2}$ in 2016. Dit betekent dat de totale emissies - inclusief de niet- $\mathrm{CO}_{2}$-emissies uit de landbouw - ongeveer 17,8 Mton is, waarvan de bijdrage van de land-en tuinbouwsector ongeveer $20 \%$ is.

De grootste bron van broeikasgassen is methaanemissie door pensfermentatie (40\%). Methaanemissie door mestmanagement, totale $\mathrm{N}_{2} \mathrm{O}$-emissie en totale energie gerelateerde $\mathrm{CO}_{2}$-emissies zijn verantwoordelijk voor elk ca. $20 \%$ van de totale Gelderse emissie uit de land- en tuinbouw. De emissie van broeikasgassen is niet gelijk verdeeld over Gelderland. Hoge broeikasgasemissies komen voor in de Gelderse Vallei ten gevolge van de intensieve veehouderij en in Zaltbommel en de Lingewaard door glastuinbouw.

Ten opzichte van 2005 is de totale broeikasgasemissie in 2016/2017 min of meer gelijk gebleven. Wel zijn er verschuivingen tussen sectoren opgetreden, met hogere emissies uit de melkveehouderij en vleeskalverhouderij en afname van de emissies in de pluimveehouderij, vleesveehouderij en de glastuinbouw. Deels is dit het gevolg van veranderingen in dieraantallen, maar deels zijn de verschillen ook het gevolg van afwijkende methodieken in de nulmeting en deze studie. Uit de eerdere studie bleek dat in de periode 1990-2005 er wel een duidelijke afname van de broeikasgasemissies was, van ongeveer $18 \%$. Deze afname was met name het gevolg van de strengere mestwetgeving, welke leidde tot minder dieren en een sterke daling in de stikstofaanvoer uit dierlijke mest en kunstmest naar de bodem.

De energiegerelateerde emissies zijn nu, voor deze studie, nog niet regionaal-specifiek berekend. Aanbevolen wordt om te kijken of de emissies door energie voor de glastuinbouwsector op een gedetailleerdere wijze op gemeenteniveau bepaald kan worden. Emissies en vastlegging van $\mathrm{CO}_{2}$ uit landgebruik (de emissiesector LULUCF) zijn nog niet in deze rapportage meegenomen. Vanuit de sector is er echter wel interesse om te werken aan $\mathrm{CO}_{2}$-vastlegging in landbouwbodems en ook de aanplant van meer bomen in houtwallen, agro-forestry-systemen of bosplantages kan bijdragen aan $\mathrm{CO}_{2}$-vastlegging. Als de provincie hierop wil gaan inzetten, dan zou het goed zijn om de monitoring ook uit te breiden naar de landgebruik-sector.

Deze rapportage biedt goed inzicht in de huidige omvang van de emissies voor de verschillende sectoren en emissiebronnen en kan daarmee dienen voor het prioriteren van mogelijke maatregelen om broeikasgasemissies te verminderen. De methodiek is zo opgezet dat ook voor komende jaren gemakkelijk een berekening kan worden uitgevoerd van de emissies uit de land- en tuinbouwsector in Gelderland, waarmee dit een vast onderdeel van de GEA-rapportage kan vormen. 


\section{Literatuur}

Coenen, P.W.H.G., M.C. van Zanten, P.J. Zijlema, E.J.M.M. Arets, K. Baas, A.C.W.M. van den Berghe, E.P. van Huis, G. Geilenkirchen, M. 't Hoen, M. Hoogsteen, R. te Molder, R. Droge, J.A. Montfoort, C.J. Peek, J. Vonk, S. Dellaert en W.W.R. Koch, 2018. Greenhouse gas emissions in the Netherlands 1990-2016 : National Inventory Report 2018. National Institute for Public Health and the Environment, Bilthoven.

De Vries, W., J. Kros, O. Oenema en J. de Klein, 2003. Uncertainties in the fate of nitrogen II: A quantitative assessment of the uncertainties in major nitrogen fluxes in the Netherlands. Nutr. Cycl. Agroecosyst. 66 (1), 71-102.

Gies, T.J.A., J. van Os, R.A. Smidt, H.S.D. Naeff en E.C. Vos, 2015. Geografisch Informatiesysteem Agrarische Bedrijven (GIAB) : gebruikershandleiding 2010. Wettelijke Onderzoekstaken Natuur \& Milieu, Wageningen, $86 \mathrm{pp}$.

IPCC, 2007. Climate Change 2007: The Physical Science Basis. Contribution of Working Group I to the Fourth Assessment Report of the Intergovernmental Panel on Climate Change Cambridge University Press, Cambridge, United Kingdom and New York, NY, USA, 996 pp.

Kros, J., K.F.A. Frumau, A. Hensen en W. De Vries, 2011. Integrated analysis of the effects of agricultural management on nitrogen fluxes at landscape scale. Environ. Pollut. 159 (11), 3171-3182.

Kros, J., J. van Os, J.C.H. Voogd, P. Groenendijk, C. van Bruggen, G.H. Ros en R. te Molder, 2018. Ruimtelijke allocatie van mesttoediening en ammoniakemissie : Beschrijving mestverdelingsmodule INITIATOR versie 5. WENR rapport 2939 Wageningen Environmental Research, Wageningen.

Lesschen, J.P., P.J. Kuikman en I.J.J.v.d. Wyngaert, 2009. Nulmeting emissie broeikasgassen Gelderse land- en tuinbouw. Alterra, Wageningen.

Oenema, O., 2015. CDM-advies Mestverwerkingspercentages 2016.

Van Bruggen, C., A. Bannink, C.M. Groenestein, J.F.M. Huijsmans, H.H. Luesink, S.M. van der Sluis, G.L. Velthof en J. Vonk, 2018. Emissies naar lucht uit de landbouw in 2016 : Berekeningen met het model NEMA. Wettelijke Onderzoekstaken Natuur \& Milieu, Wageningen.

Van Bruggen, C., A. Bannink, C.M. Groenestein, J.F.M. Huijsmans, H.H. Luesink, S.V. Oude Voshaar, S.M. van der Sluis, G.L. Velthof en J. Vonk, 2017. Emissies naar lucht uit de landbouw in 2014. Statutory Research Tasks Unit for Nature \& the Environment, Wageningen.

Van der Velden, N.J.A. en P.X. Smit, 2018. Protocol Energiemonitor Glastuinbouw : Vernieuwde versie tot en met 2017. Wageningen Economic Research, Wageningen.

Van Os, J., L.J.J. Jeurissen en H.S.D. Naeff, 2016. Geografisch informatiesysteem voor de emissieregistratie van landbouwbedrijven; GIABplus-bestand 2013 - Status A. WOT technical report: 66 Wettelijke Onderzoekstaken Natuur \& Milieu, Wageningen.

Vonk, J., S.M. van der Sluis, A. Bannink, C. van Bruggen, C.M. Groenestein, J.F.M. Huijsmans, J.W.H. van der Kolk, L.A. Lagerwerf, H.H. Luesink, S.V. Oude Voshaar en G.L. Velthof, 2018. Methodology for estimating emissions from agriculture in the Netherlands; update 2018 : calculations of $\mathrm{CH}_{4}, \mathrm{NH}_{3}, \mathrm{~N} 2 \mathrm{O}, \mathrm{NO}$, PM10, PM2.5 and $\mathrm{CO}_{2}$ with the National Emission Model for Agriculture (NEMA). Statutory Research Tasks Unit for Nature \& the Environment, Wageningen. 


\section{Bijlage 1 Korte beschrijving van het model INITIATOR}

De broeikasgasemissies op gemeenteniveau zijn berekend met het model INITIATOR (Integrated Nitrogen Impact Assessment Tool on a Regional Scale). Dit model simuleert de productie en verdeling van mest en houdt daarbij rekening met aanvoer van dierlijke mest (van het eigen bedrijf of via mesttransport) en kunstmest, wettelijke gebruiksnormen, het gewas en de bodemeigenschappen.

\section{Modeloverzicht}

INITIATOR is een relatief eenvoudig en flexibel model dat alle belangrijke $\mathrm{N}$ - en P-fluxen op regionale schaal berekent, waaronder de aanvoer van $\mathrm{N}$ en $\mathrm{P}$ in de vorm van kunstmest, dierlijke mest en depositie en daarnaast nog $\mathrm{N}$-binding, $\mathrm{N}$ - en P-opname door het gewas, emissie van stikstofgassen, te weten ammoniak $\left(\mathrm{NH}_{3}\right)$, lachgas $\left(\mathrm{N}_{2} \mathrm{O}\right)$ en stikstofoxiden $\left(\mathrm{NO}_{x}\right)$ en de emissie van methaan $\left(\mathrm{CH}_{4}\right)$ naar de atmosfeer en uit- en afspoeling van nitraat, ammonium en fosfaat naar grond- en oppervlaktewater. Daarnaast berekent het model ook de emissies van het broeikasgas methaan, de verandering in de voorraad aan bodemkoolstof en de bijbehorende emissie of vastlegging van $\mathrm{CO}_{2}$ uit bodems en de accumulatie en uitspoeling van basen (verzuring) en zware metalen (lood, cadmium, koper en zink). Voor een uitgebreide beschrijving van INITIATOR wordt verwezen naar De Vries et al. (2003) en Kros et al. (2011).

De $\mathrm{N}$ - en P-excretie worden berekend door een vermenigvuldiging van het aantal dieren (in verschillende categorieën) met zogenoemde excretiefactoren, die aangeven hoeveel mest elk dier in een jaar produceert. De stal- en opslagemissies van gasvormige N-verliezen worden berekend door de $\mathrm{N}$ - excretie te vermenigvuldigen met $\mathrm{N}$-emissiefracties, waarbij rekening wordt gehouden met dier-en staltype. Een mestverdelingsmodule berekent vervolgens het transport van dierlijke mest op gemeenteniveau en de aanvoer van mest en kunstmest naar de bodem. De $\mathrm{NH}_{3}$-emissie uit stallen en opslagen en vanuit de bodem vormen de input van het atmosferisch transportmodel OPS voor de berekening van de $\mathrm{N}$-depositie op zowel landbouwgronden als in Natura 2000-gebieden.

Een bodemmodule berekent vervolgens wat er met de nutriënten gebeurt: accumulatie, opname, gasvormige emissies of uit- en afspoeling naar het watersysteem. Bij de berekening is een regionale differentiatie aangebracht door rekening te houden met verschillen in bodemgebruik, grondsoort en grondwaterstand, die bepalend zijn voor de optredende processen. Voor de P-modellering is voor Psorptie gebruikgemaakt van een combinatie van een snelle en langzame pool met een bodemtype afhankelijke parametrisatie.

Het model maakt gebruik van gedetailleerde ruimtelijke gegevens die grotendeels afkomstig zijn uit beschikbare nationale GIS-datasets, zoals de geografisch expliciete landbouwtellinggegevens, met het aantal dieren per vestiging (GIAB-plus; Van Os et al., 2016). Door deze koppeling zijn we in staat om op een hoge ruimtelijke resolutie de $\mathrm{N}$ - en P-excretie, stal- en opslagemissies, mest- en kunstmestverdeling, bodememissie, uit- en afspoeling en $\mathrm{N}$-depositie te berekenen.

Gebruikte modelinvoer voor de berekening van $\mathrm{CH}_{4}$ - en $\mathrm{N}_{2} \mathrm{O}$-emissie op gemeenteniveau De vereiste data voor de berekening van mineralenbalansen op gebiedsniveau zijn onder te verdelen in: (i) regionale modelinput data, (ii) modelparameters die veelal variëren als functie van bodemtype of bodemeigenschappen (bv. organischestofgehalte, kleigehalte en gehalte aan aluminium- en ijzeroxiden) en (iii) overige data, die veelal een rol spelen bij verdeling van de mest over het land. Hieronder zijn de verschillende data met hun bronnen genoemd.

\section{Modelinput}

De input van het model bestaat in grote lijnen uit:

- gedetailleerde ruimtelijke gegevens ten aanzien van bodem (bodemtype, C-, N-, P- en metaalgehaltes), hydrologie, landgebruik en gewassen die grotendeels afkomstig zijn uit 
beschikbare nationale GIS-datasets: de 1:50.000 bodemkaart en het landgebruik (STONE voor de ruimtelijke verdeling, CBS voor de absolutie hoeveelheid);

- geografisch expliciete landbouwtellinggegevens, met o.a. het aantal dieren per bedrijf, het staltype en de locatie van stallen (GIAB-plus), in het model geaggregeerd tot bedrijfsniveau;

- mestverwerking en export (CBS) op nationaal niveau (voor rundvee-, varkens- en pluimveemest), welke vervolgens is neergeschaald naar gemeenteniveau;

- gewasopbrengsten (CBS), nationale cijfers per gewas (grasland, maïs, aardappelen, tarwe, suikerbieten, overig graan en overige gewassen).

In het Geografisch Informatiesysteem Agrarische Bedrijven (GIAB; Gies et al., 2015) is informatie over verschillende grondgebruiksfuncties een belangrijke basis om effecten van beleidsmaatregelen te analyseren of om nieuwe ontwerpen te maken. Hierin zijn gegevens opgenomen van landbouwbedrijven die meedoen aan de jaarlijkse landbouwtelling van het CBS en RVO. De gegevens zijn gekoppeld aan de locatie van de hoofdvestiging van het landbouwbedrijf. Het bestand wordt onder andere gebruikt bij onderzoek naar dierziekten, landbouwstructuuranalyses, effecten van het Gemeenschappelijk Landbouwbeleid en bij onderzoek naar emissies van geur, ammoniak en fijnstof. Voor sommige jaren zijn ook gegevens van de Gezondheidsdienst voor Dieren toegevoegd aan het GIAB. Belangrijke variabelen zijn: het bedrijfstype, de bedrijfsomvang, arealen per gewas en aantallen per diergroep. Vanaf 2011 is ook de verdeling van dieren over de nevenvestigingen en de ligging daarvan beschikbaar.

\section{Modelparameters}

De volgende modelparameters worden meegenomen:

- excretiefactoren en de verdeling van de mest over weide- en stalmest: deze zijn afkomstig uit NEMA (Van Bruggen et al., 2017);

- ammoniak-, methaan- en lachgas-emissiefactoren, afkomstig uit NEMA (Van Bruggen et al., 2017);

- nitrificatie- en denitrificatiefactoren (De Vries et al. (2003);

- elementgehaltes in gewassen: literatuurgegevens;

- adsorptie-/desorptieconstanten voor fosfaat, sulfaat en metalen: literatuurgegevens.

\section{Overige data}

- normen ten aanzien van maximale mestgiften voor $\mathrm{N}$ en $\mathrm{P}$;

- acceptatiegraden voor dierlijke mest op basis van berekende acceptaties uit de mestverwerkingspercentages (Oenema, 2015);

- bedrijven met derogatie (RVO). 


\section{Bijlage 2 Indeling diercategorieën INITIATOR}

\begin{tabular}{lll} 
Diertype & RAV-code & Diercategorie \\
\hline Melkvee & A1 & melk/kalfkoeien $>2 \mathrm{jr}$ \\
\hline Vleesvee & A3 & vrouwelijk jongvee $<2 \mathrm{jr}$ \\
\hline & A2 & zoogkoeien \\
\hline Vleeskalveren & vleesstieren en overig vleesvee van circa 8 tot 24 maanden (roodvleesproductie) \\
\hline & A7 & fokstieren en overig rundvee ouder dan 2 jaar \\
\hline Varkens & A4 & vleeskalveren, rosé \\
\hline & D12 & vleeskalveren, wit \\
\hline D13 & kraamzeugen (incl. biggen tot spenen) \\
\hline D2 & Dekberen, $>=7$ mnd. \\
\hline D3 & Vleesvarkens, opfokberen en -zeugen \\
\hline E1 & Opfokhennen en hanen van legras < 18 wk \\
\hline E2 & Legkippen \\
\hline E3 & Ouderdieren van vleeskuikens in opfok < 19 wk \\
\hline E4 & Ouderdieren van vleeskuikens \\
\hline E5 & Vleeskuikens \\
\hline F4 & Vleeskalkoenen \\
\hline G12 & Vleeseenden en ouderdieren van vleeseenden \\
\hline B1 & Schapen > 1 jr \\
\hline C1 & Geiten > 1 jr \\
\hline H1 & Nertsen \\
\hline H2 & Vossen \\
\hline I1 & Konijnen, voedsters \\
\hline K12 & Paarden in opfok/volwassen paarden \\
\hline & Pony's (volwassen en in opfok) \\
\hline & \\
\hline
\end{tabular}




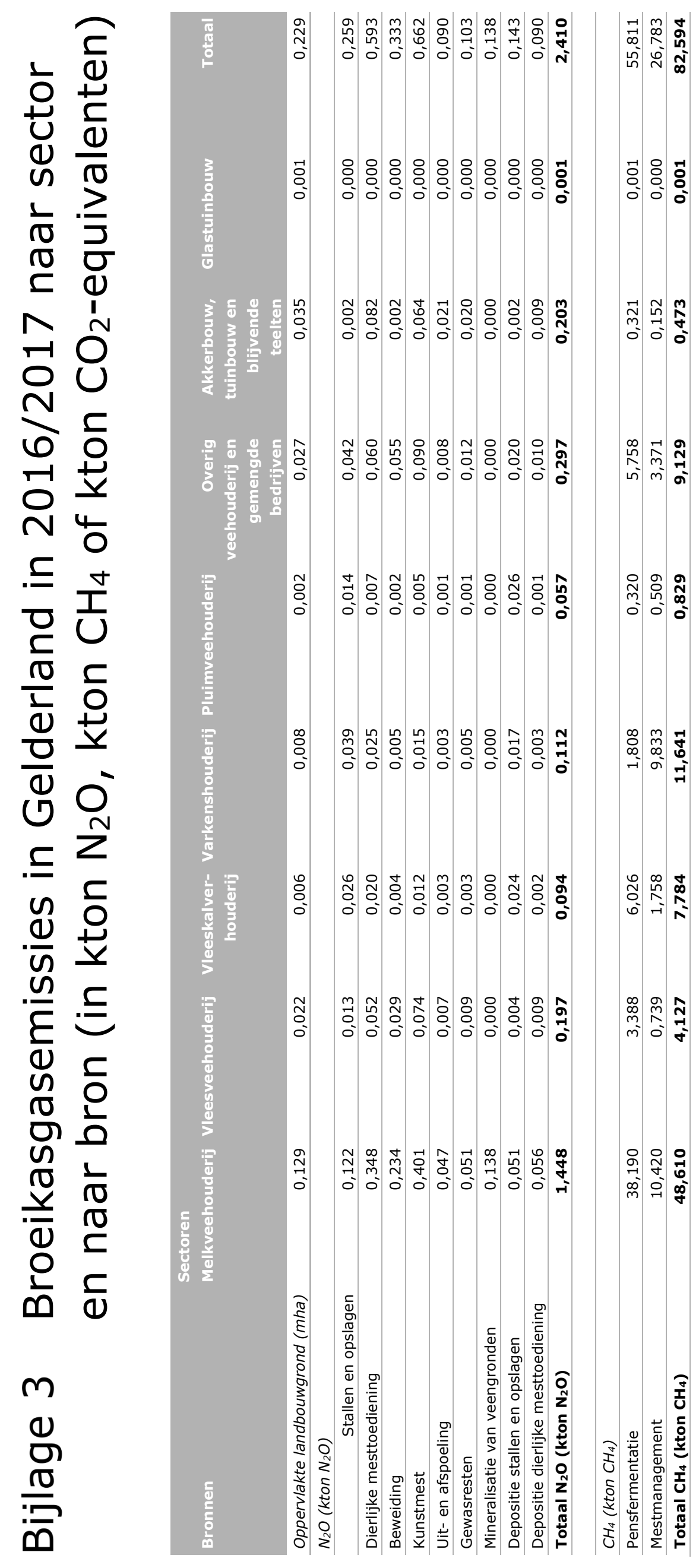




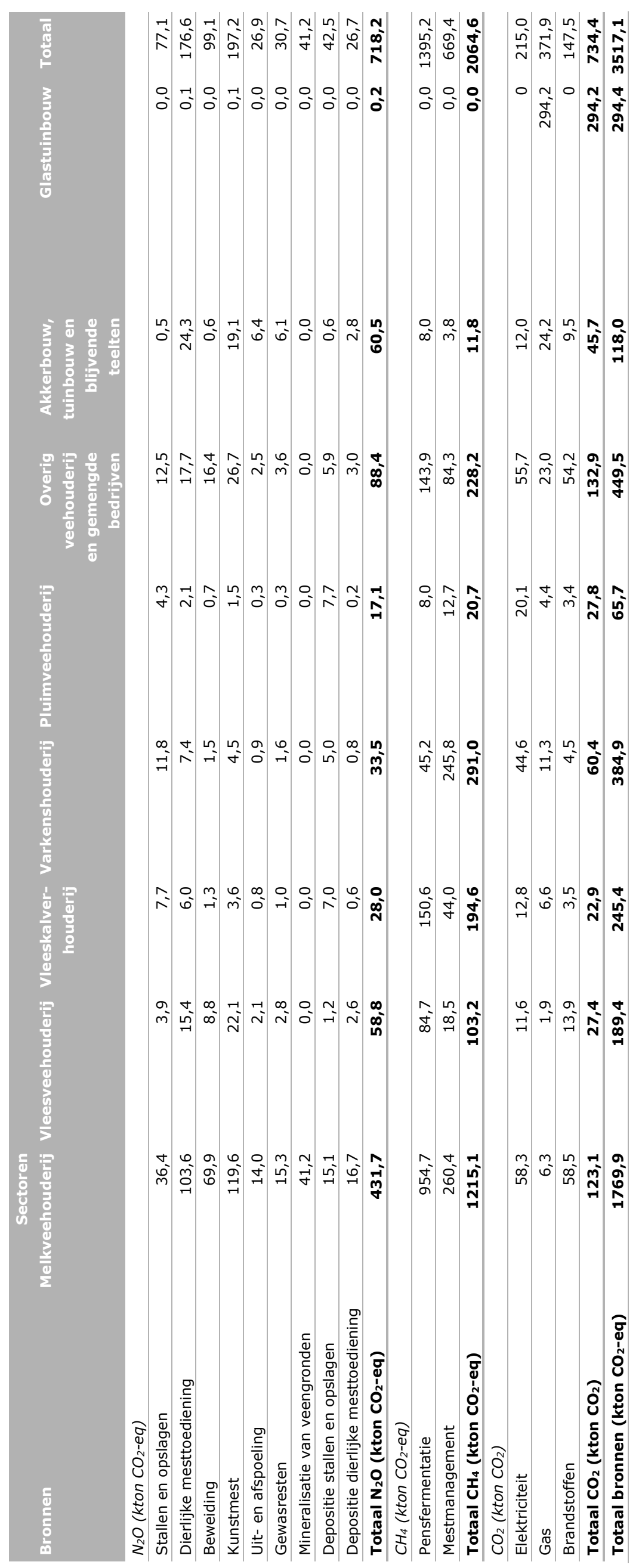




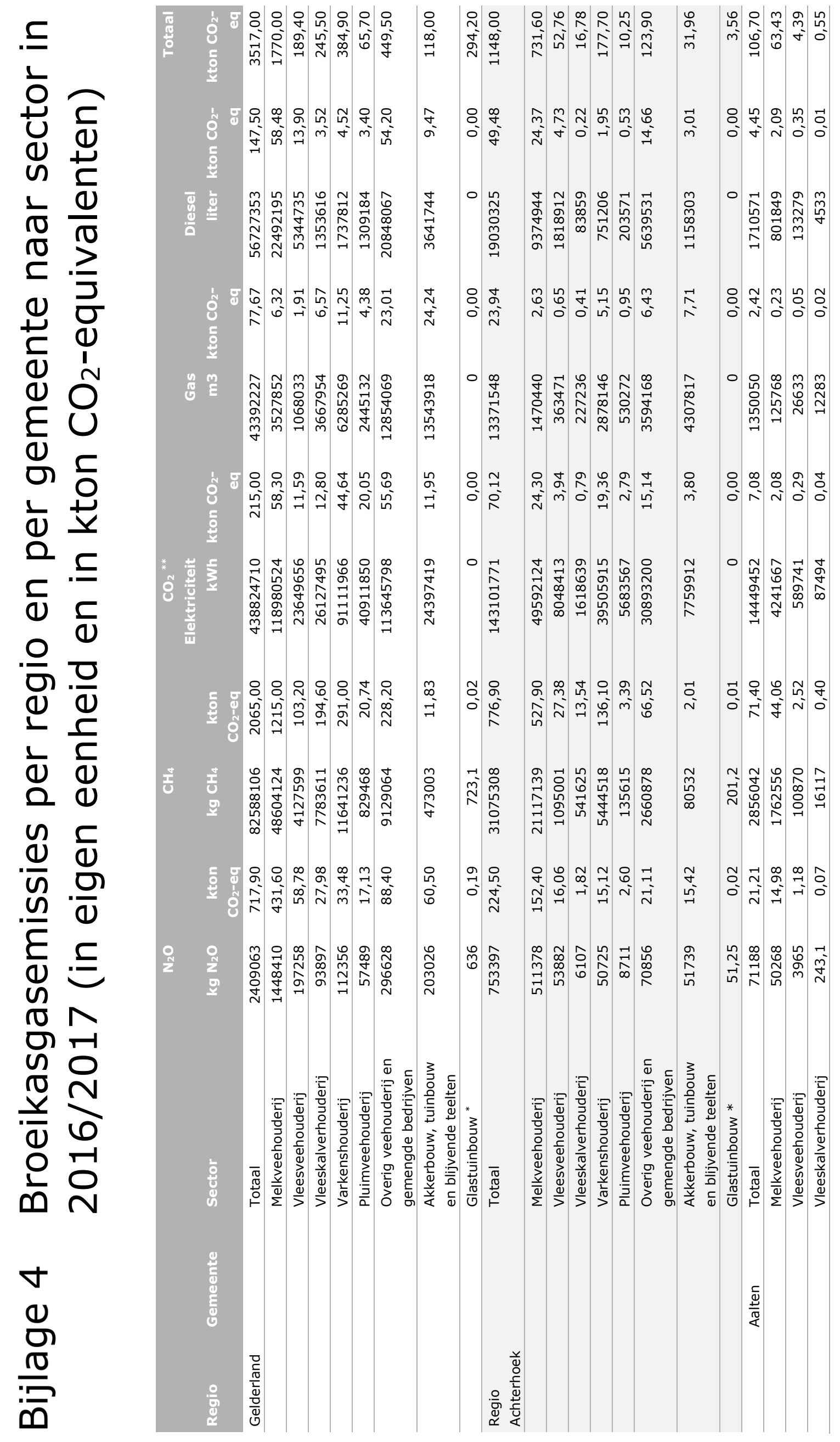




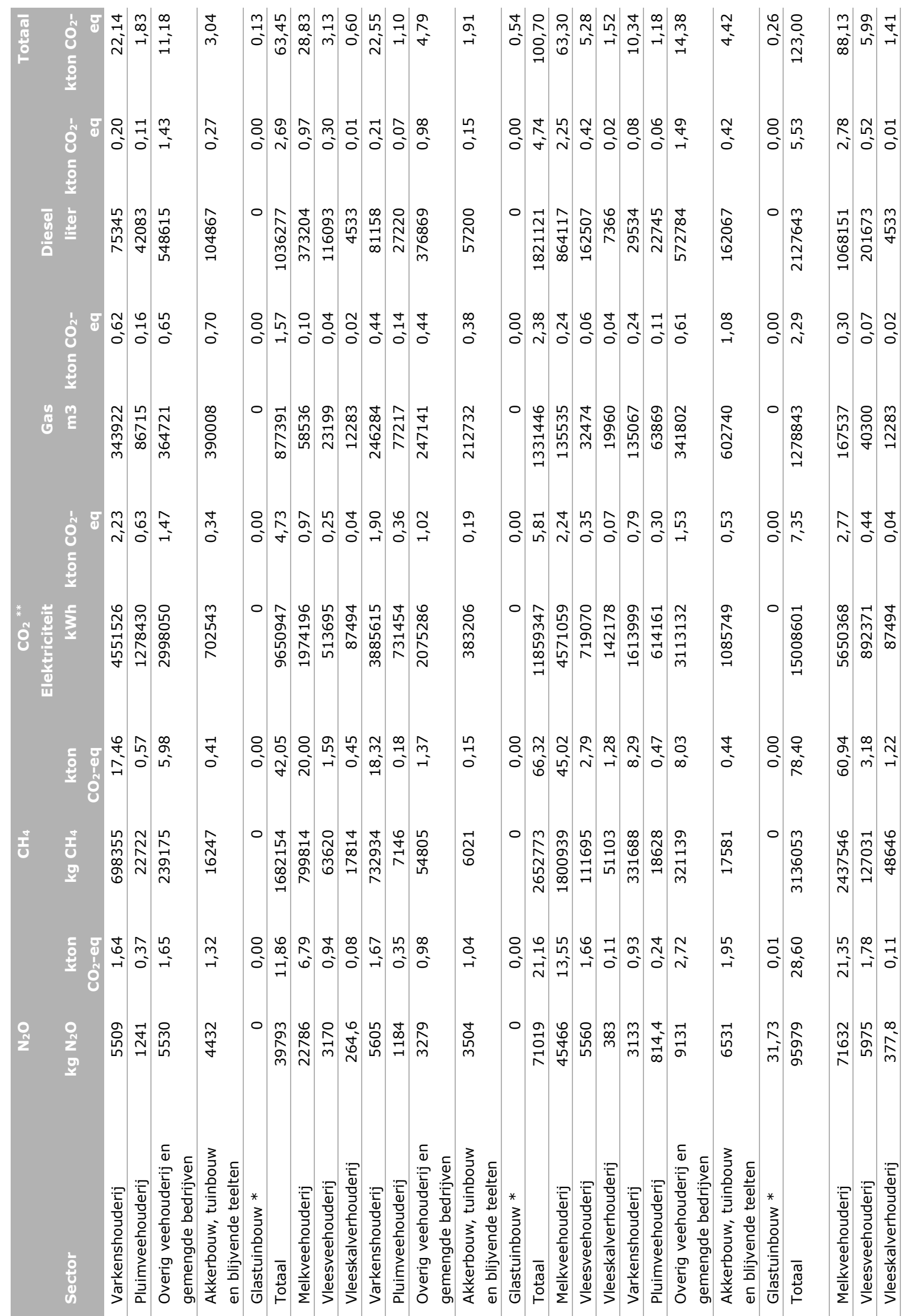

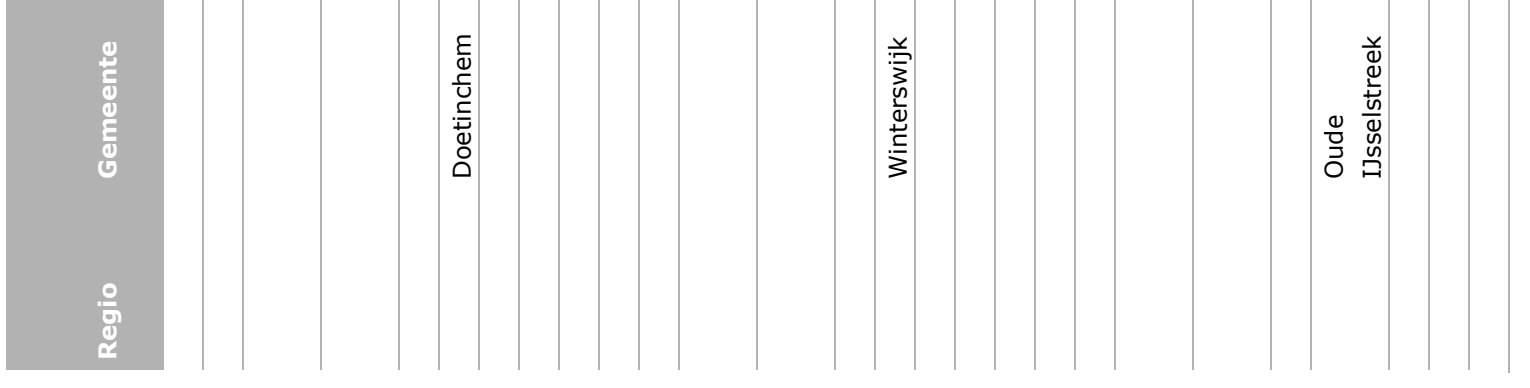




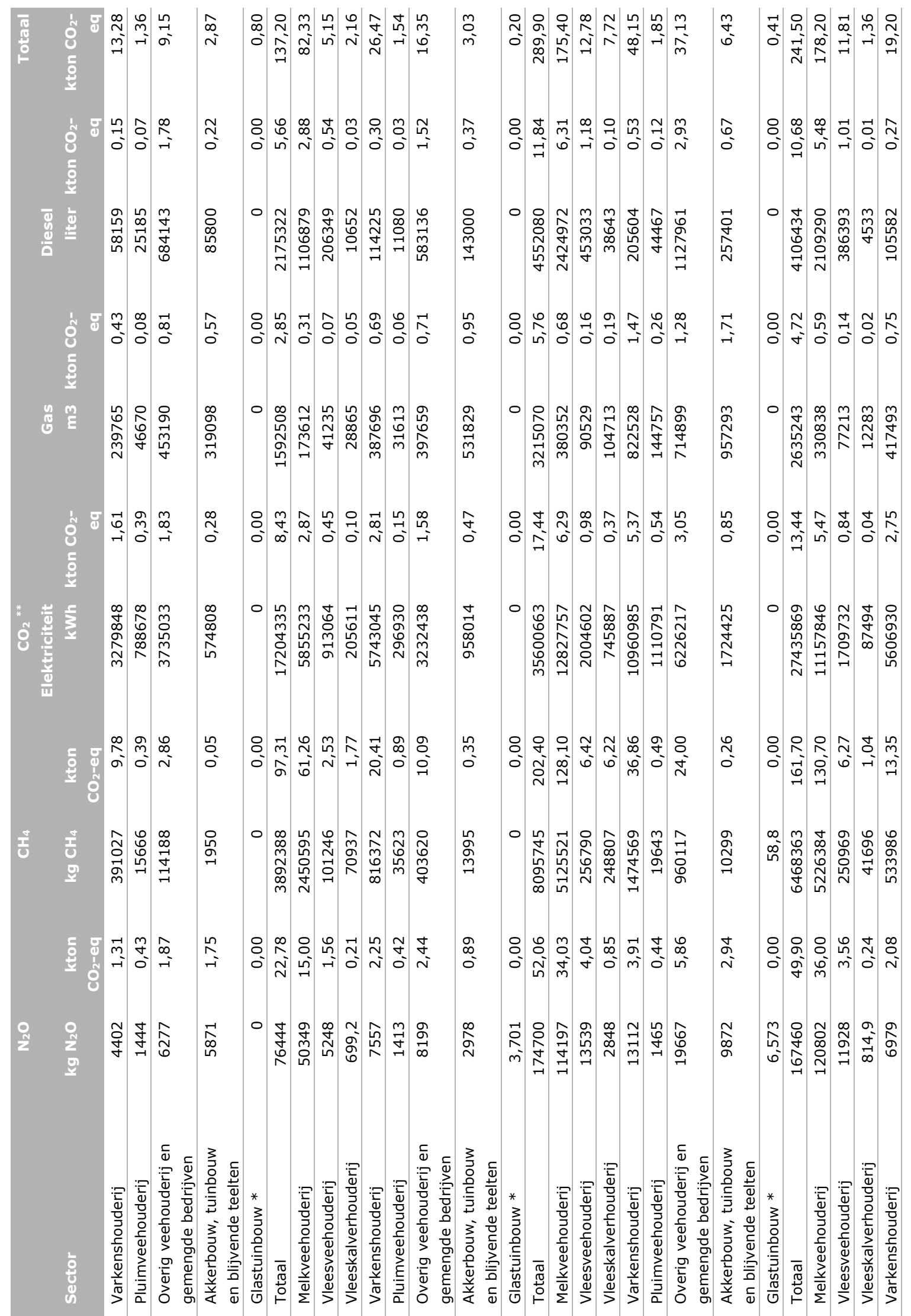
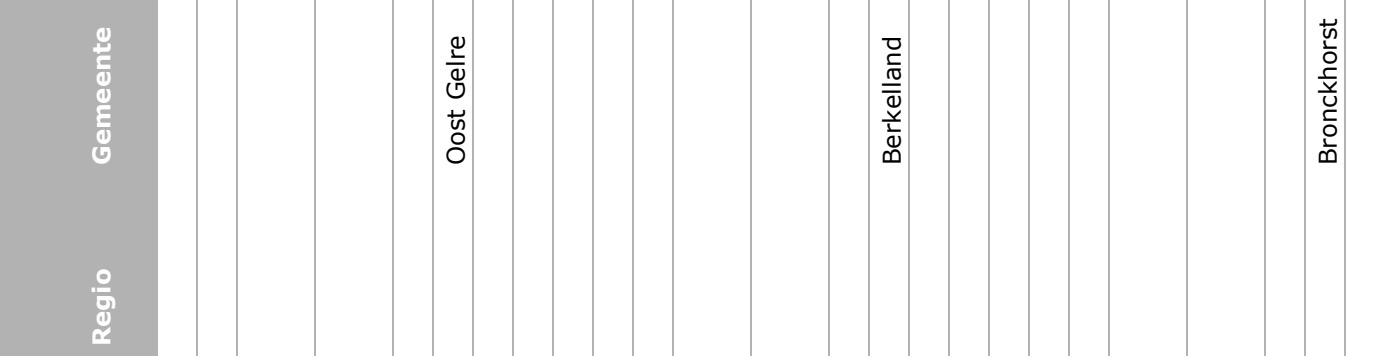


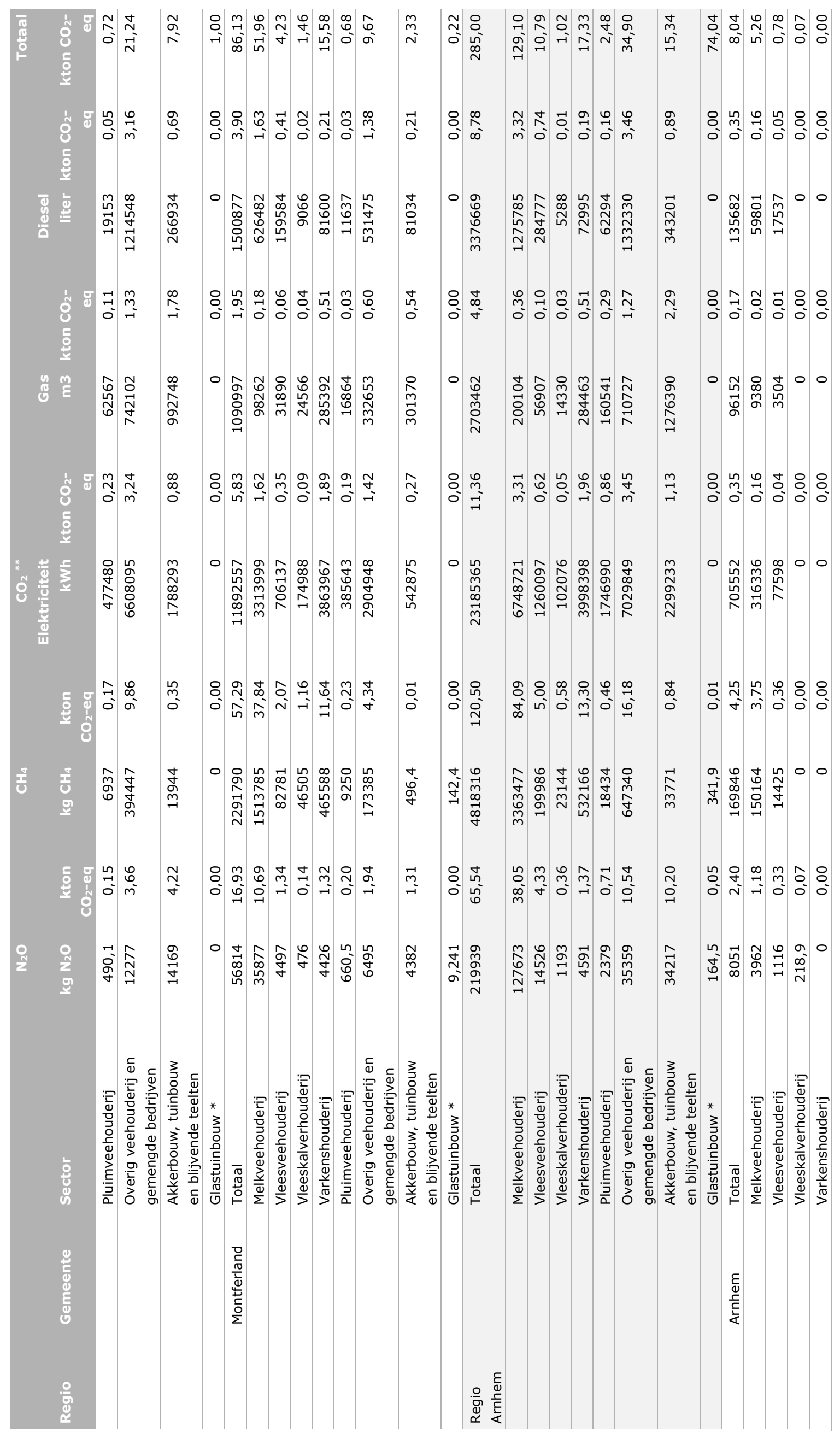




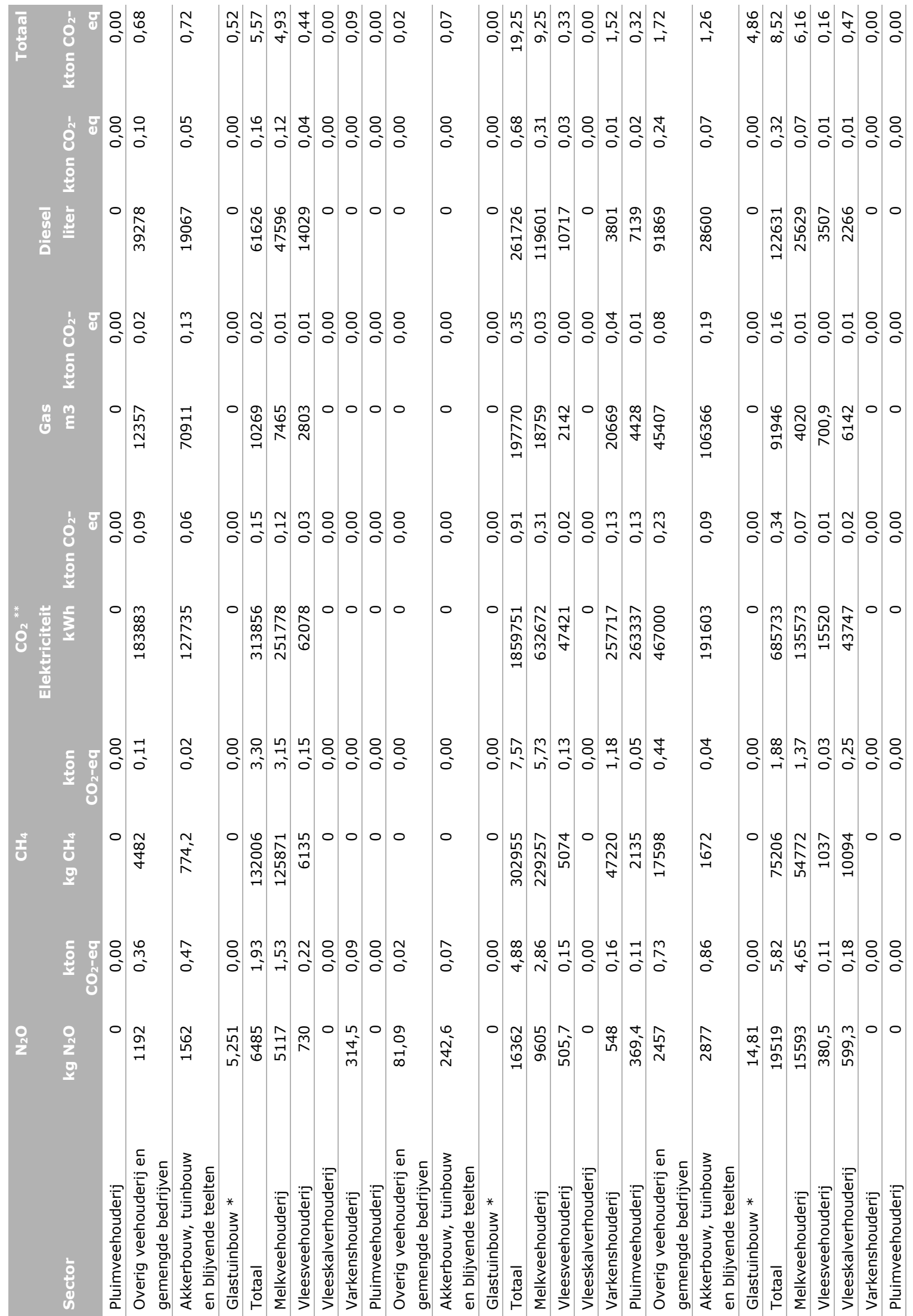




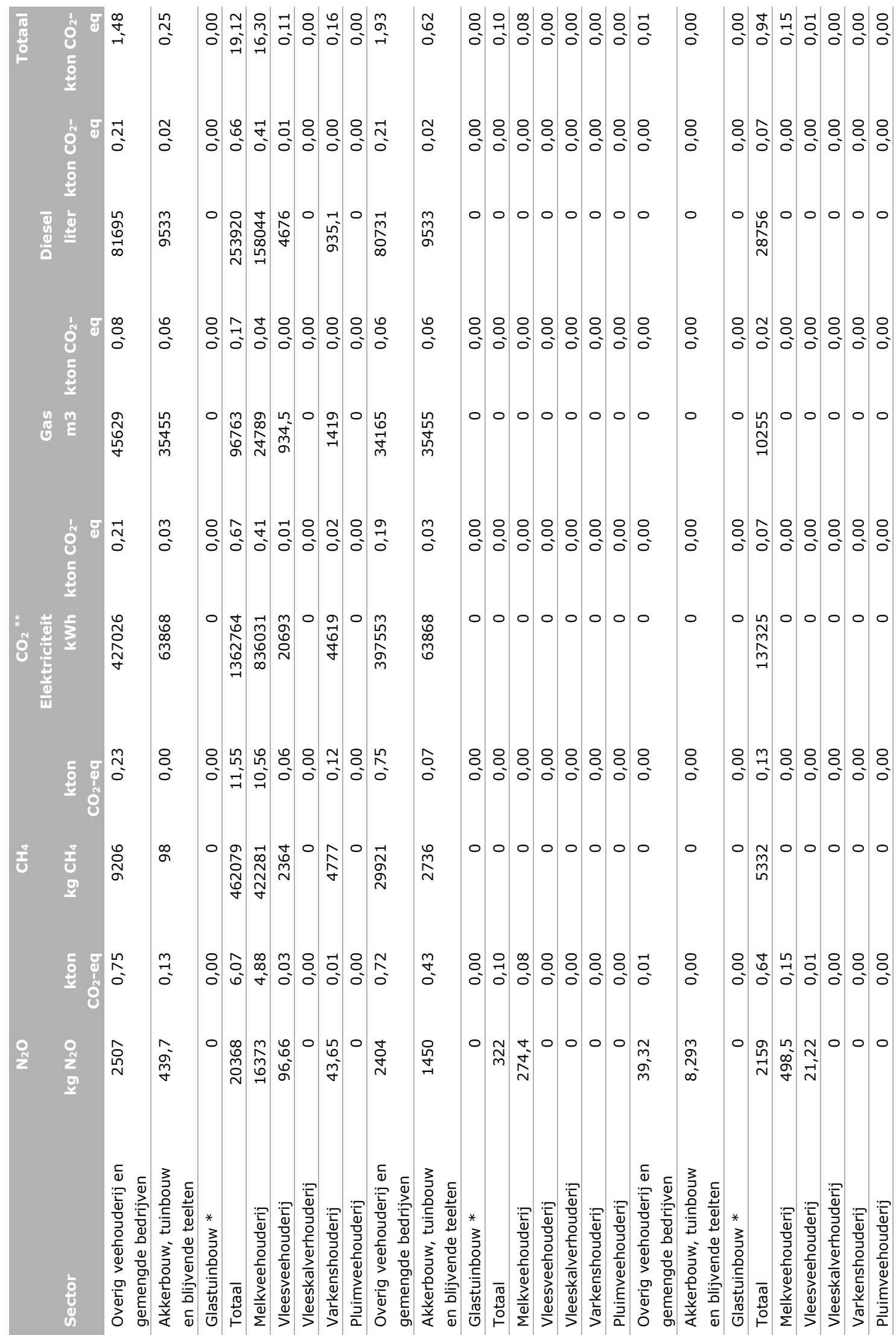




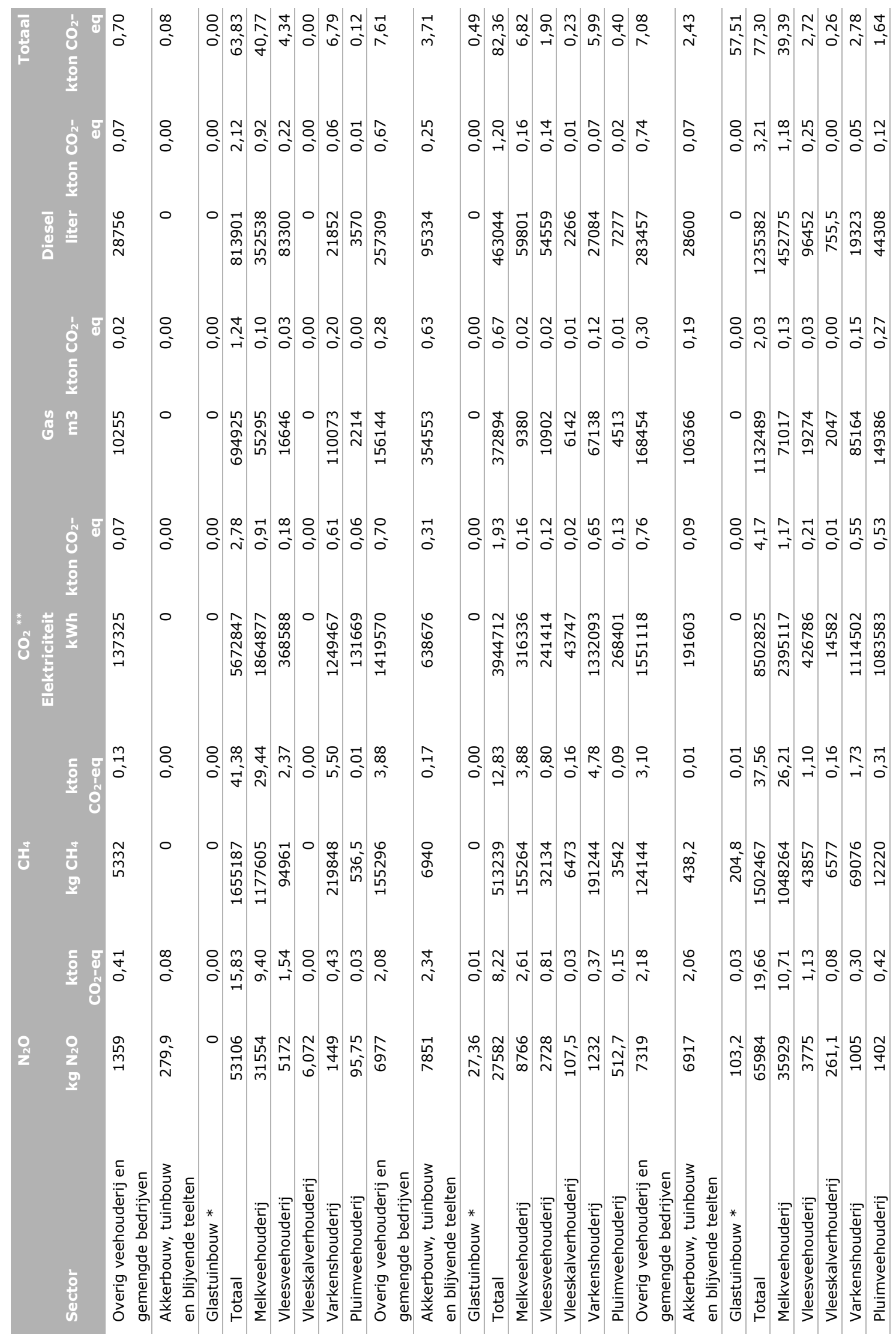




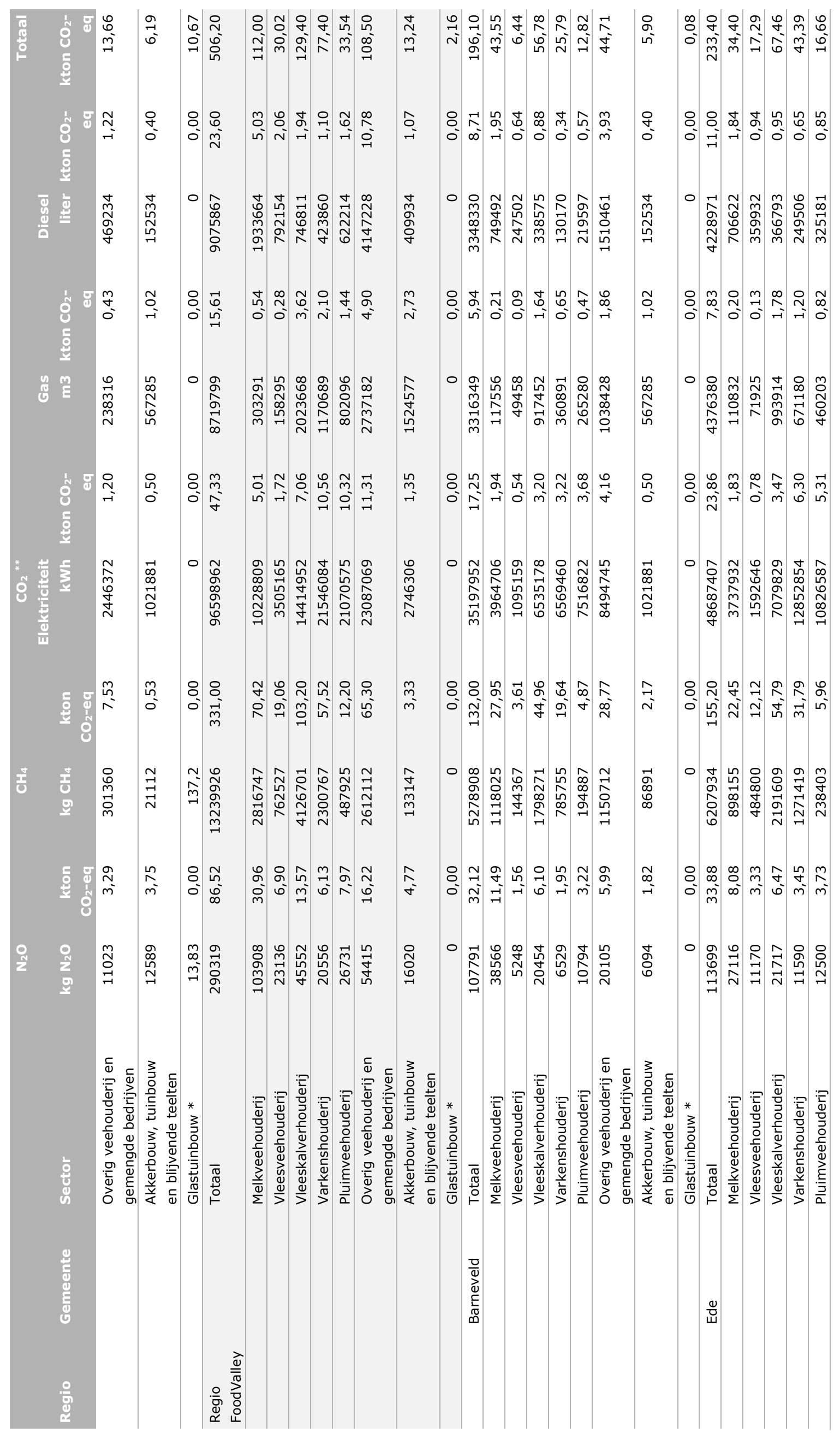




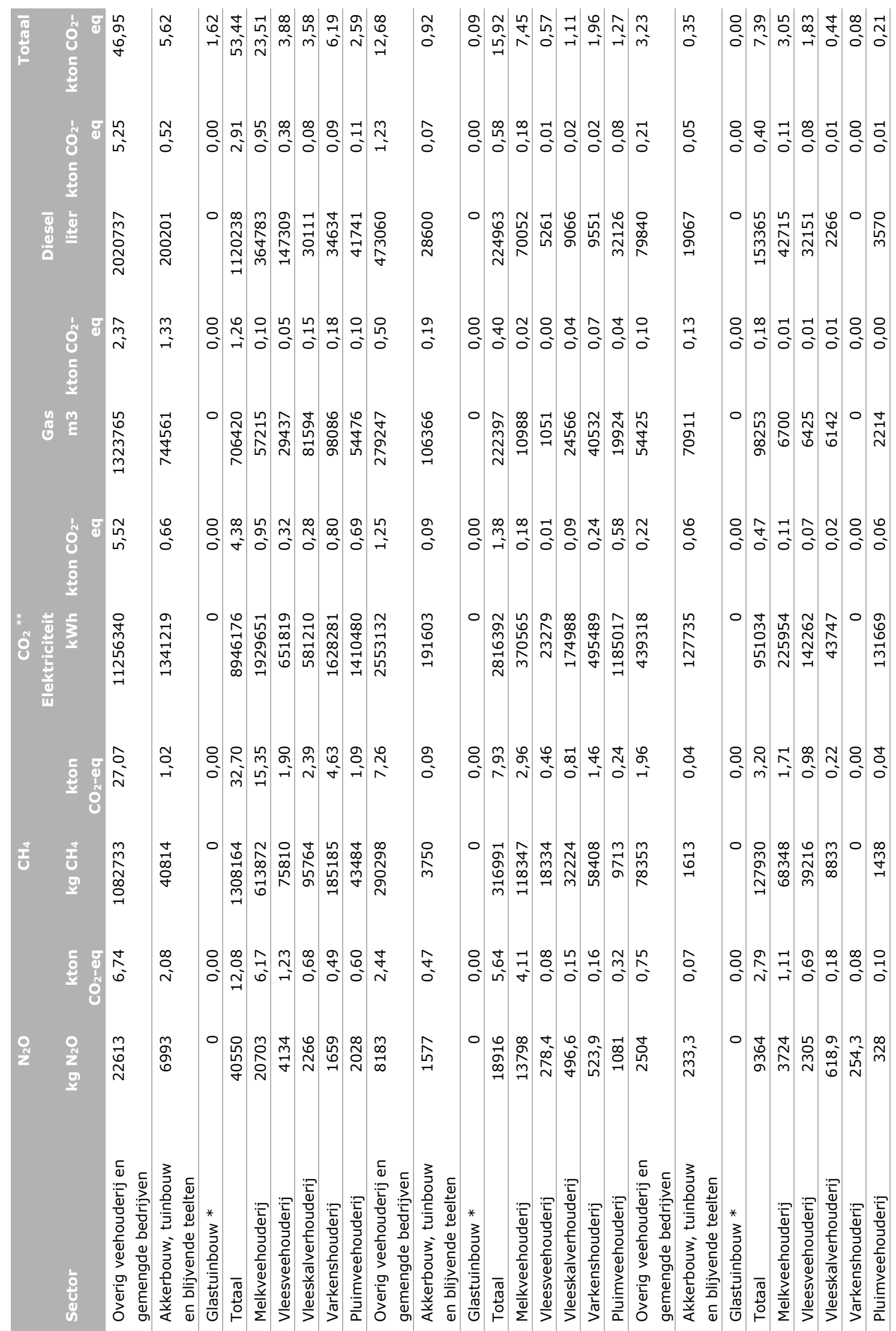




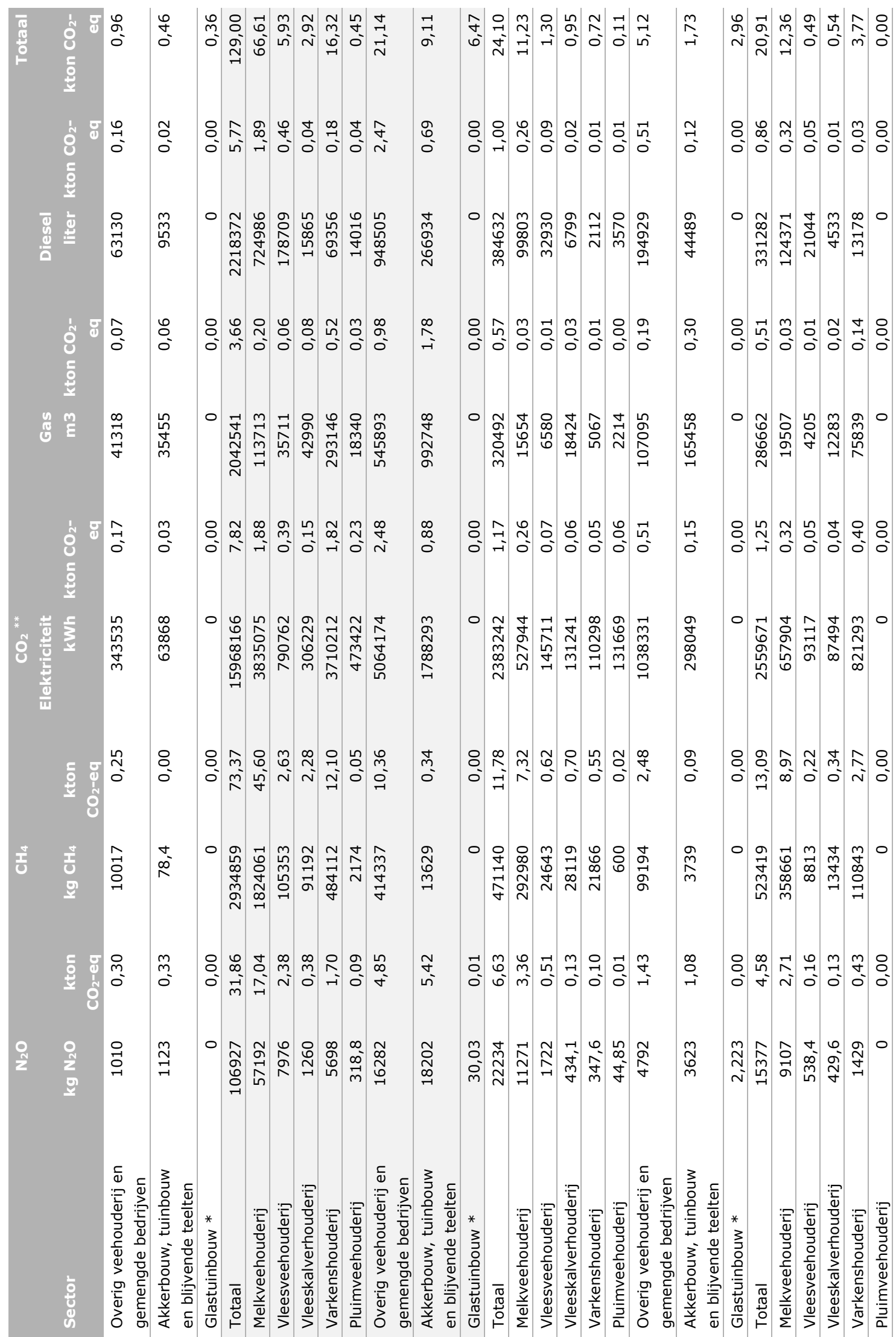




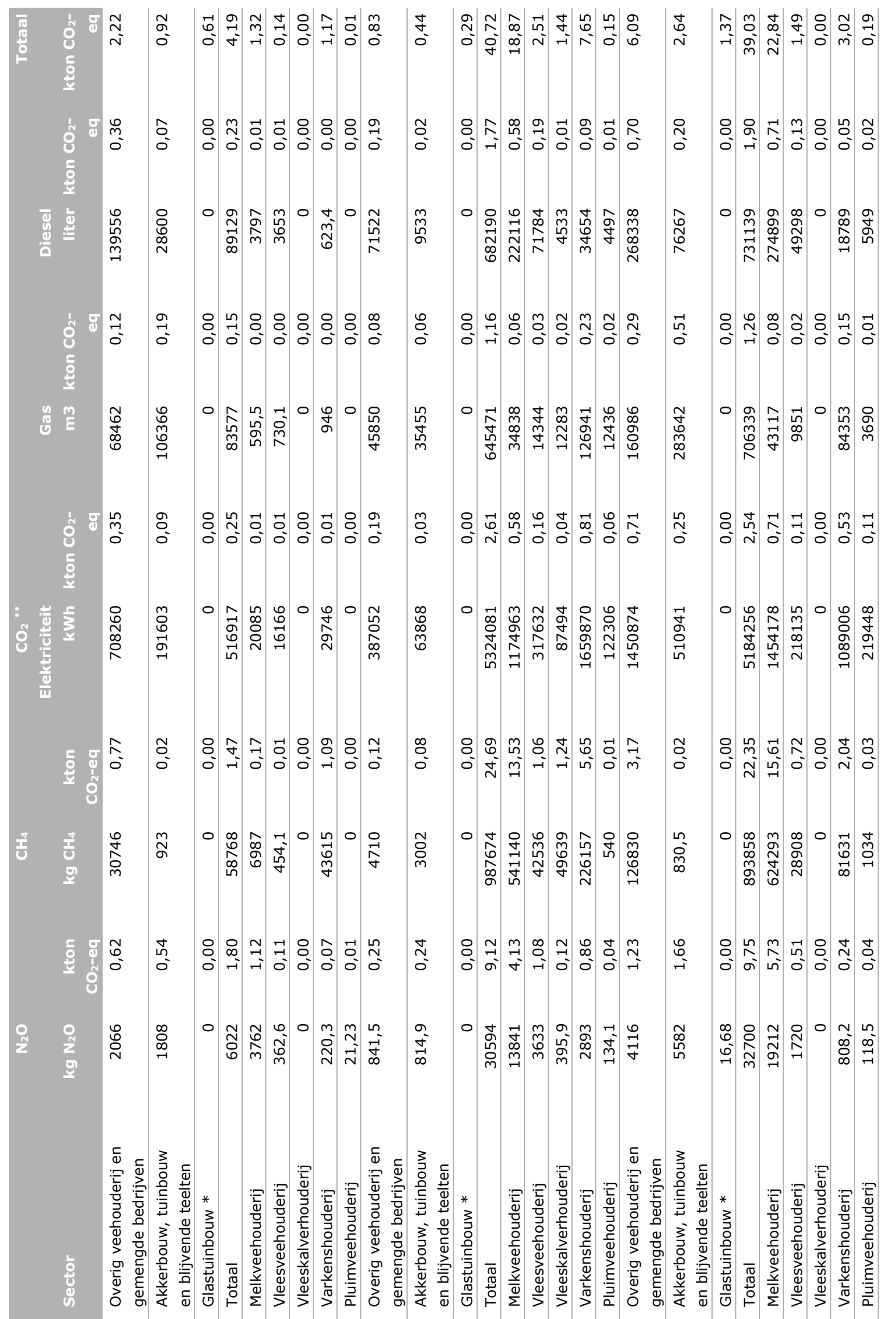




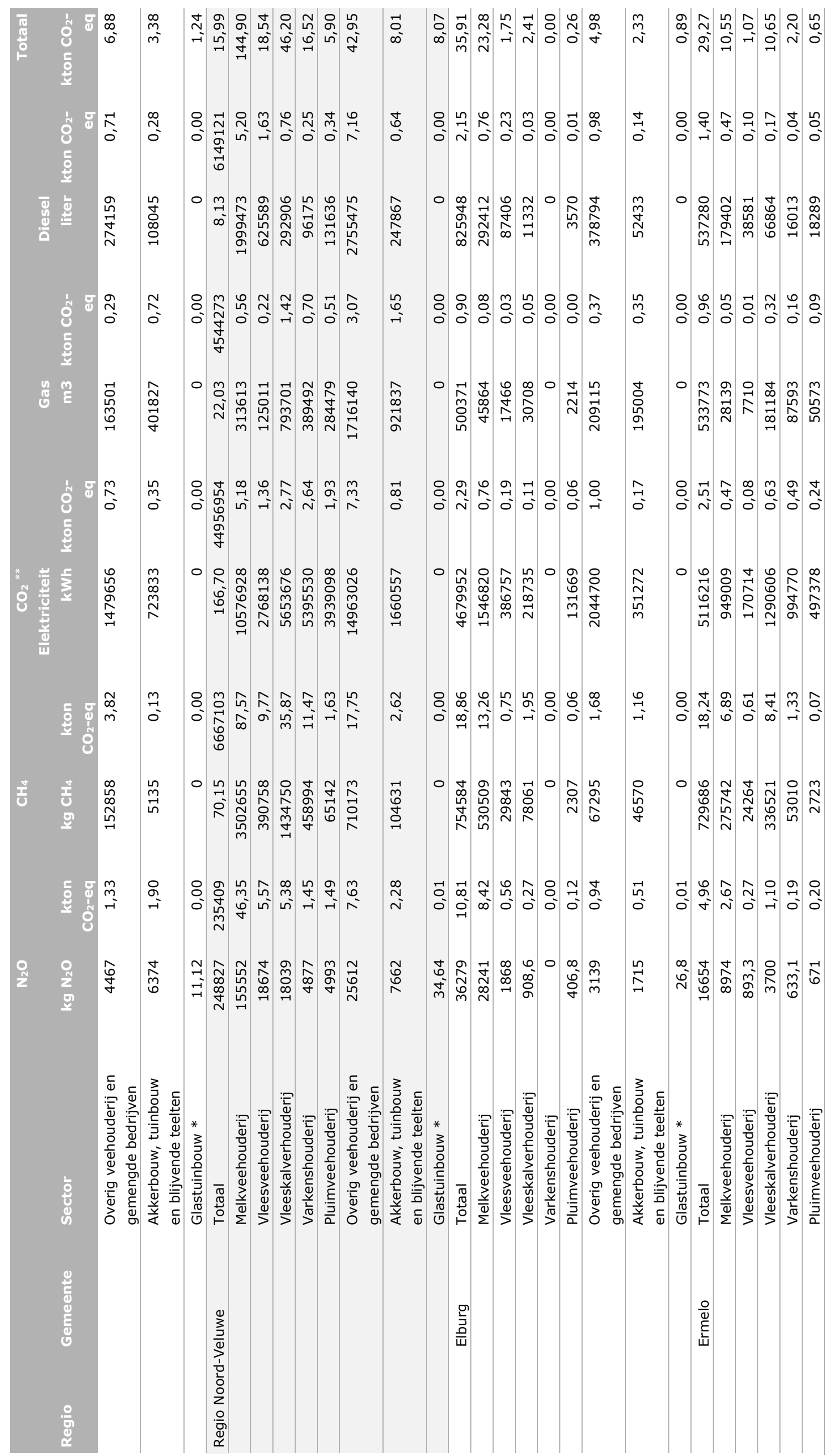




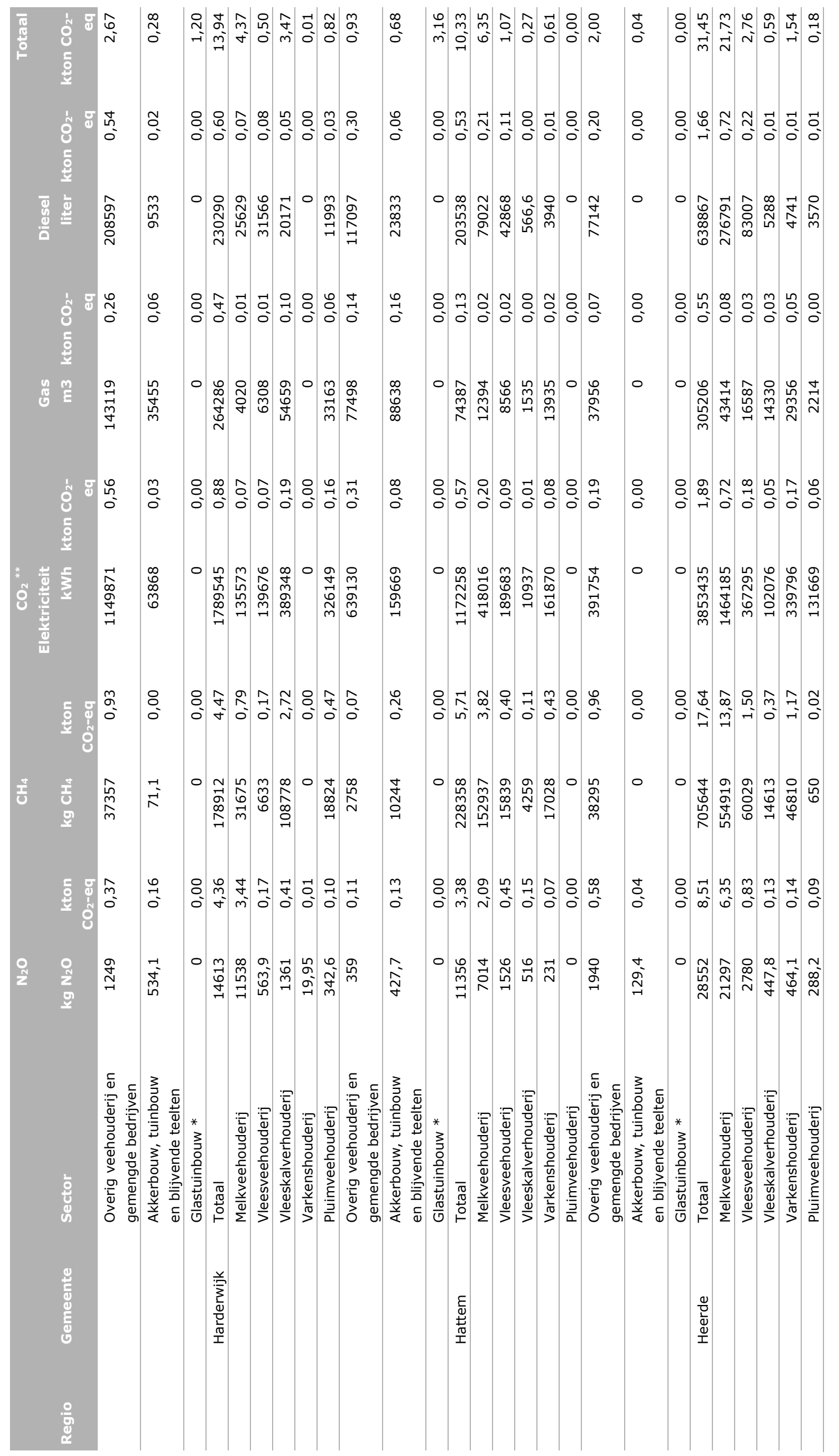




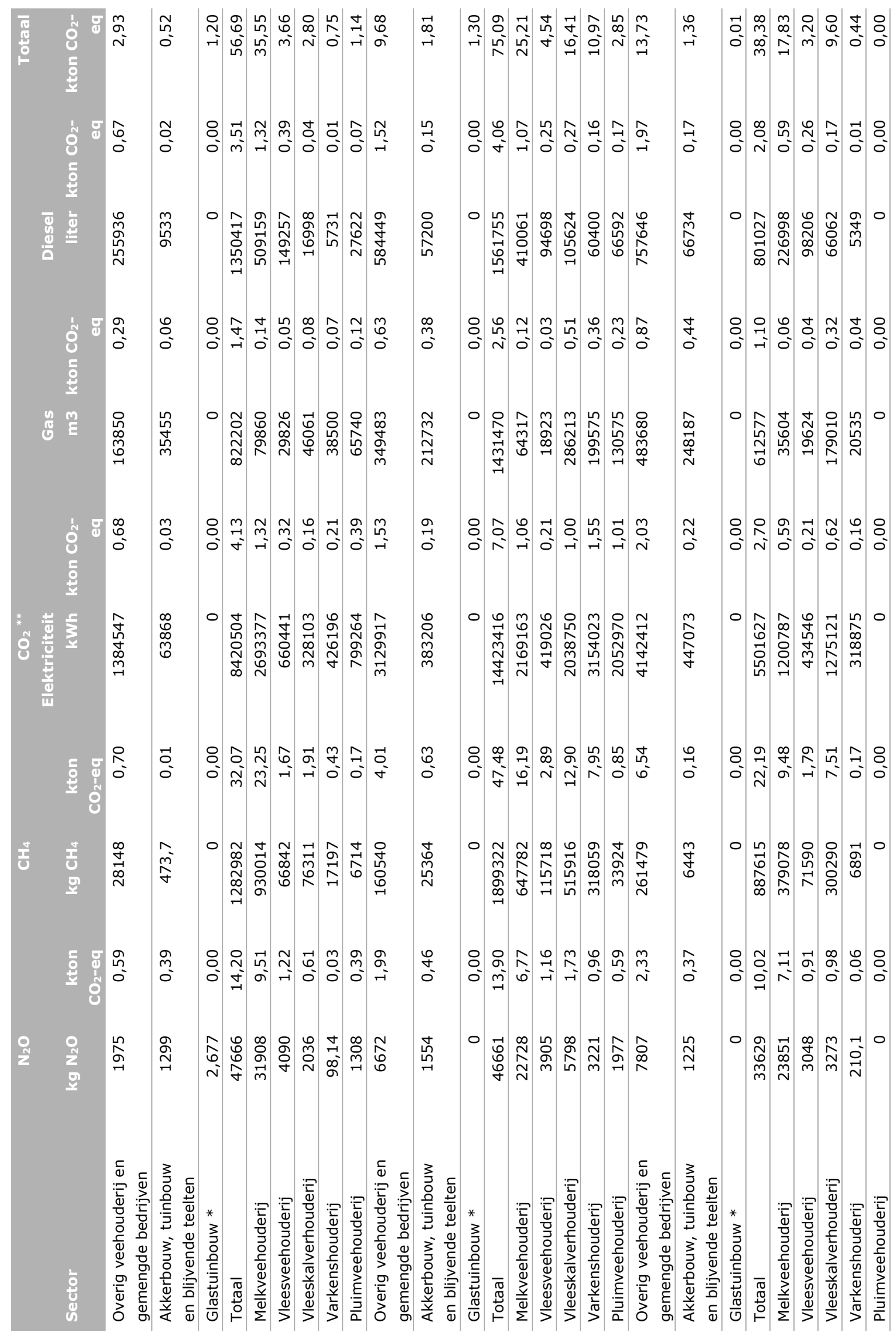




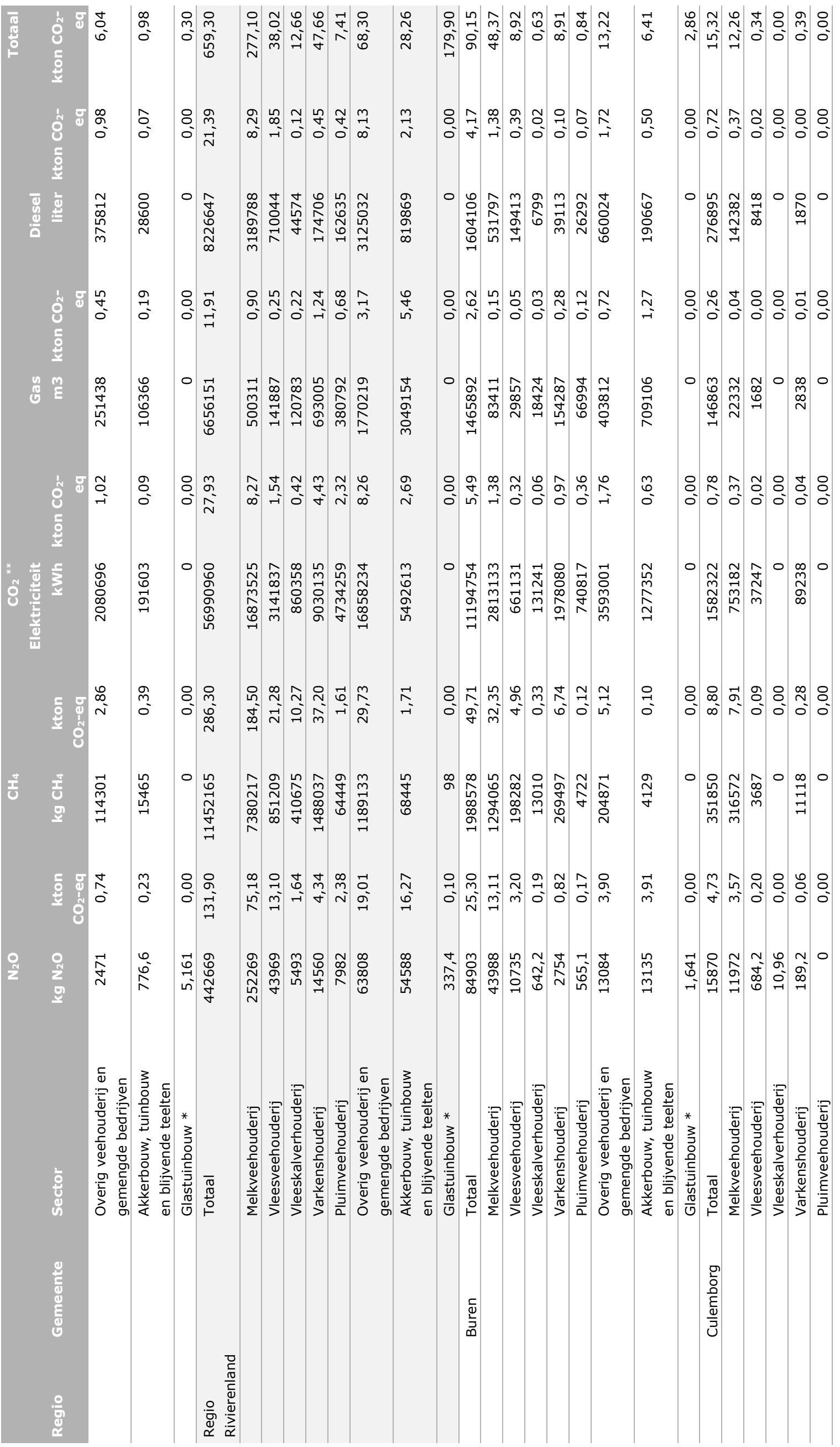




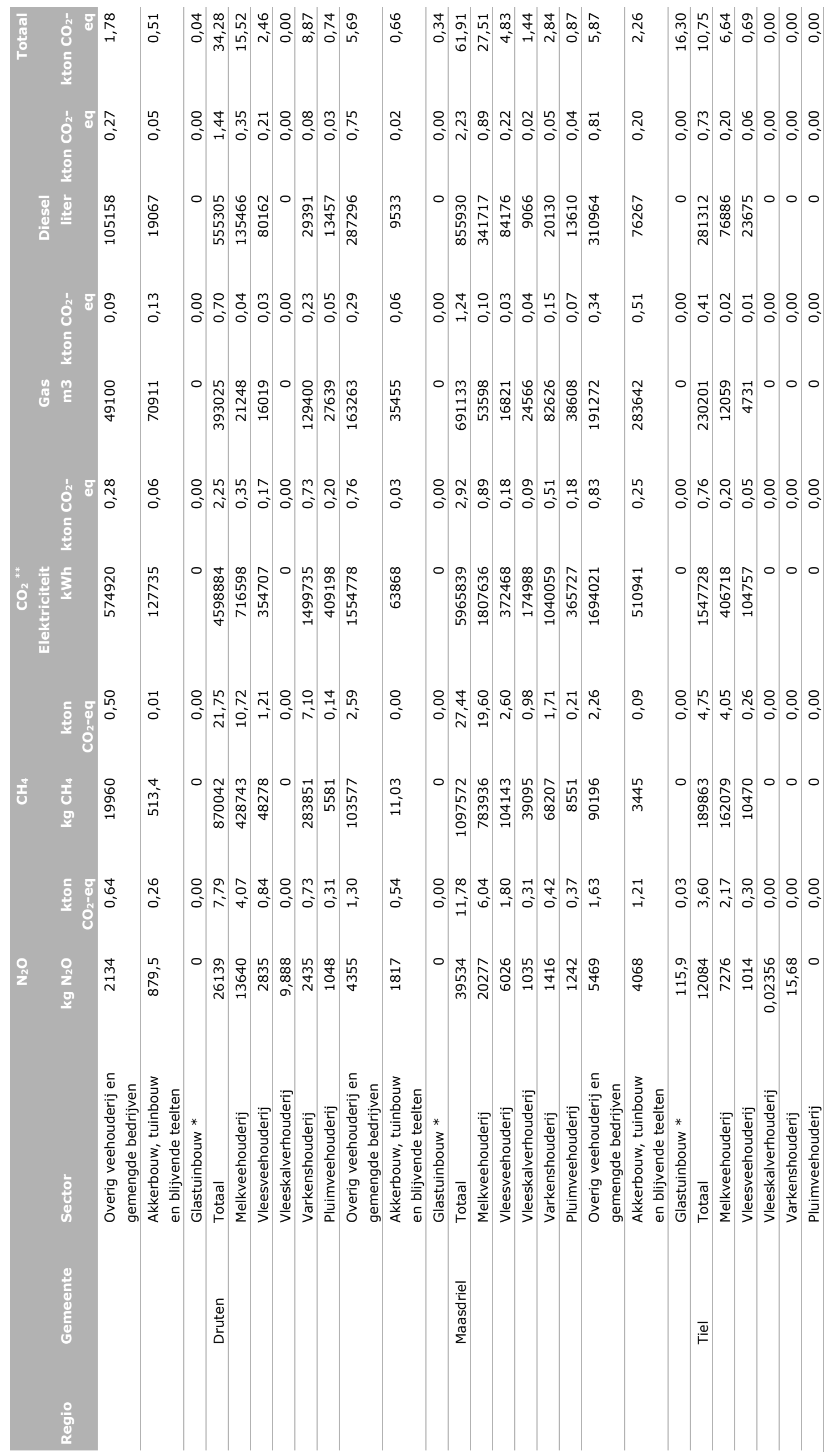




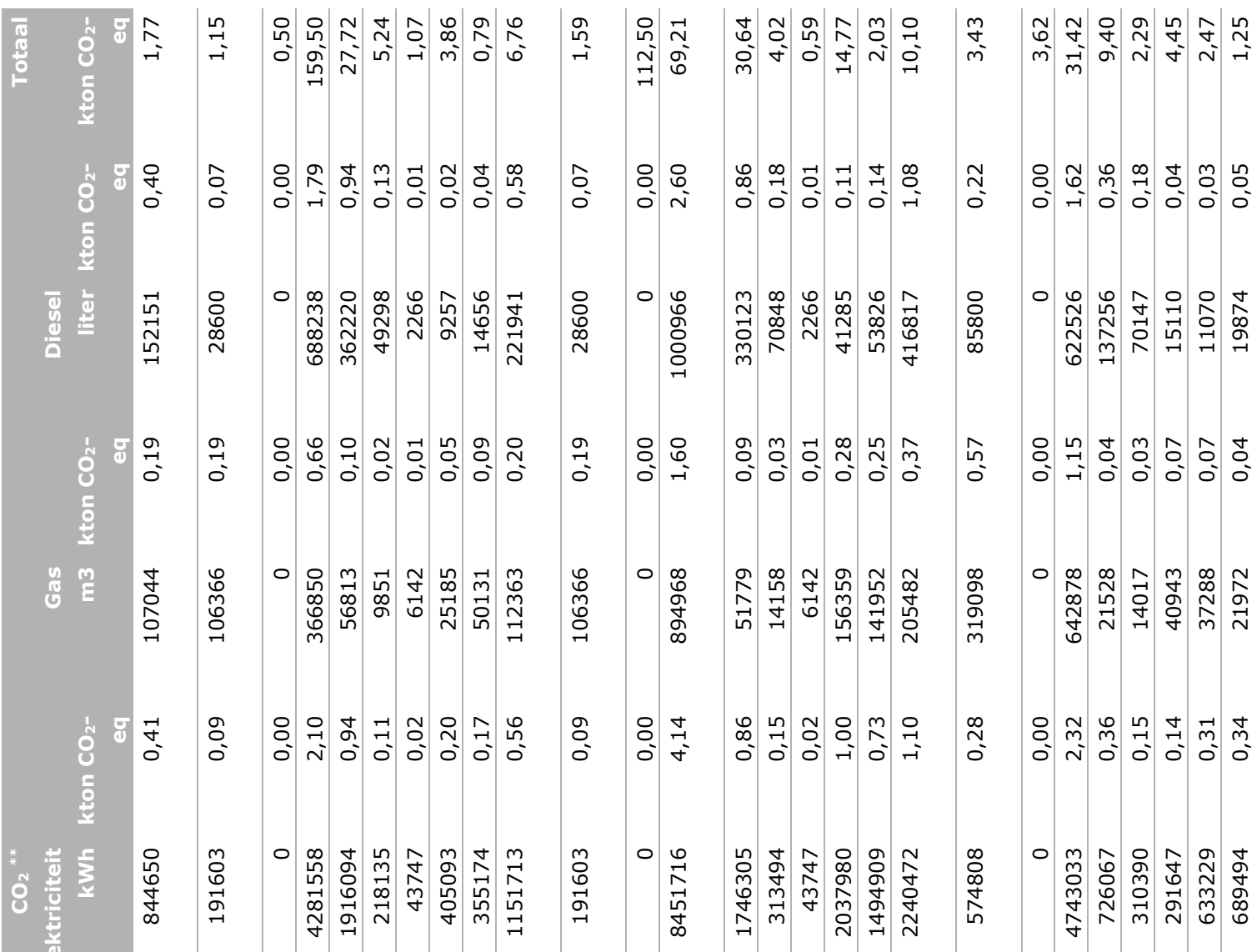

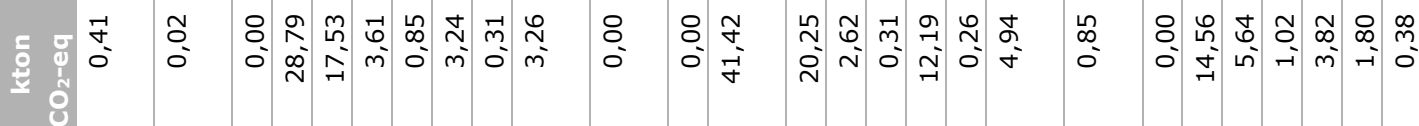

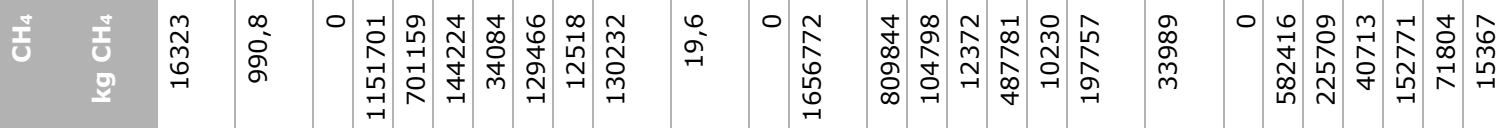

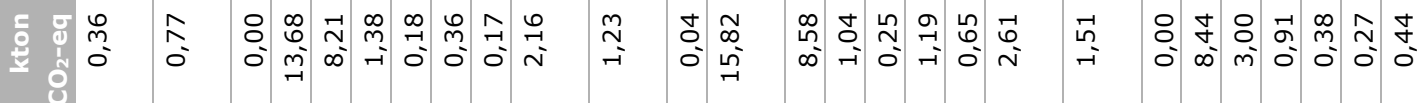

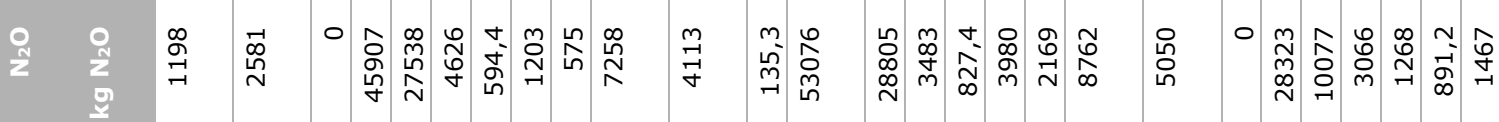

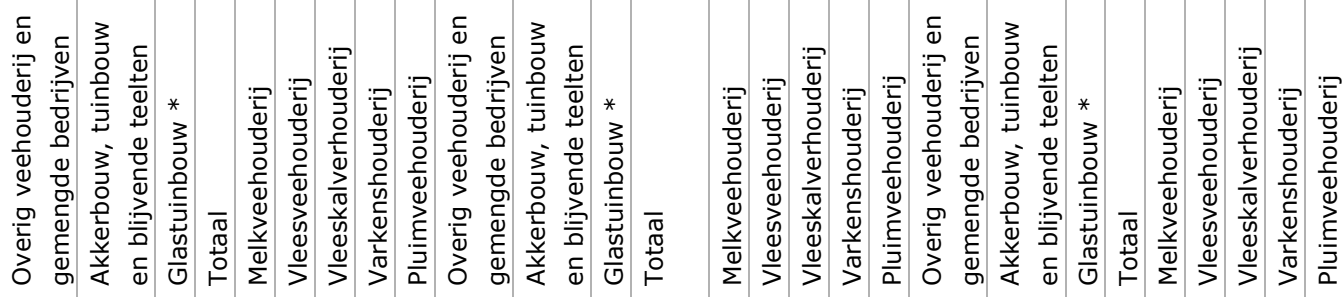

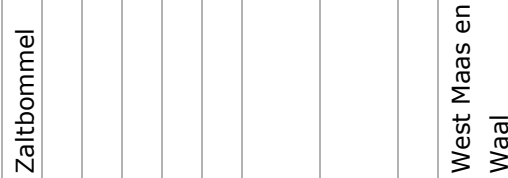

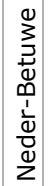




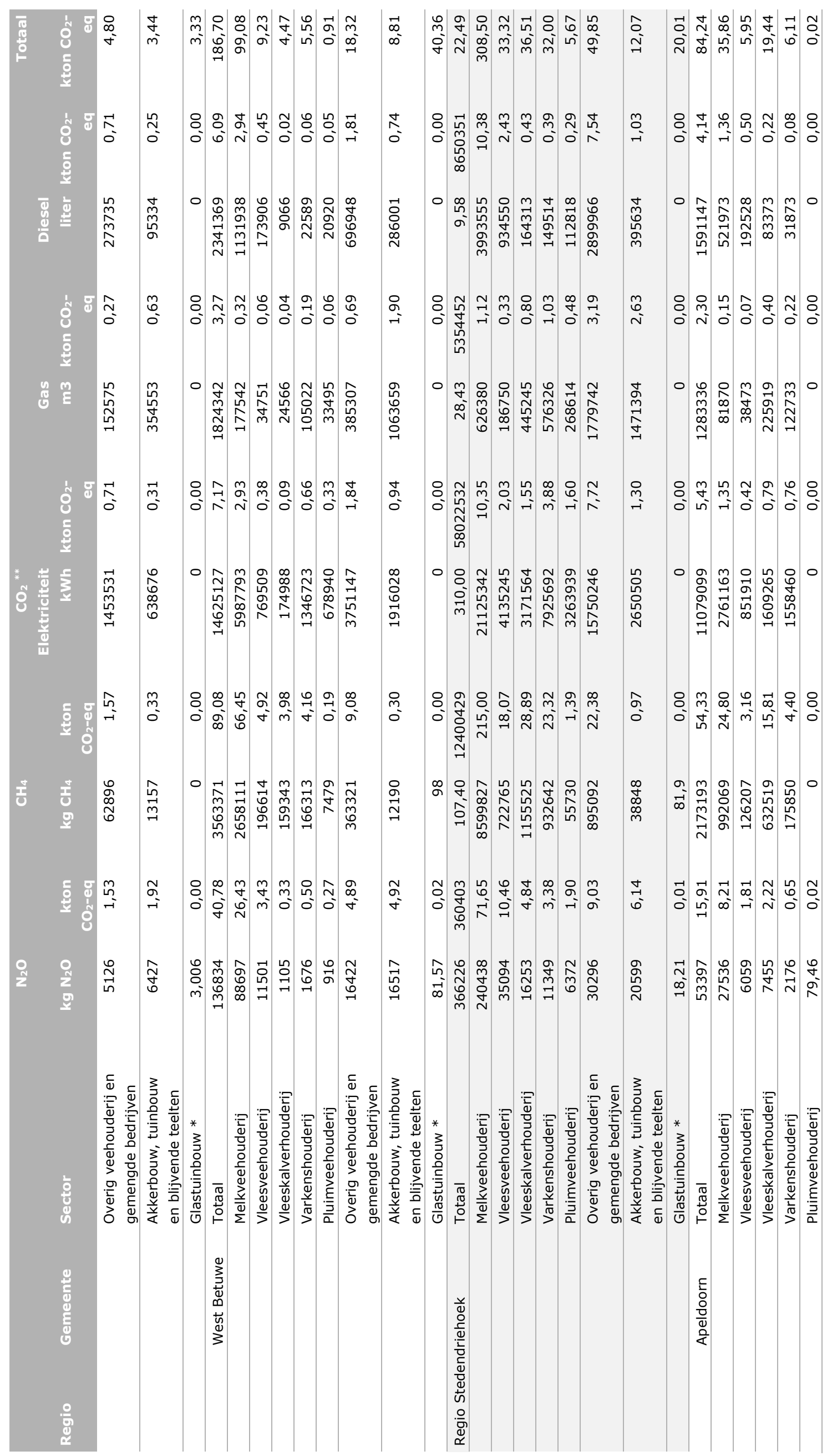




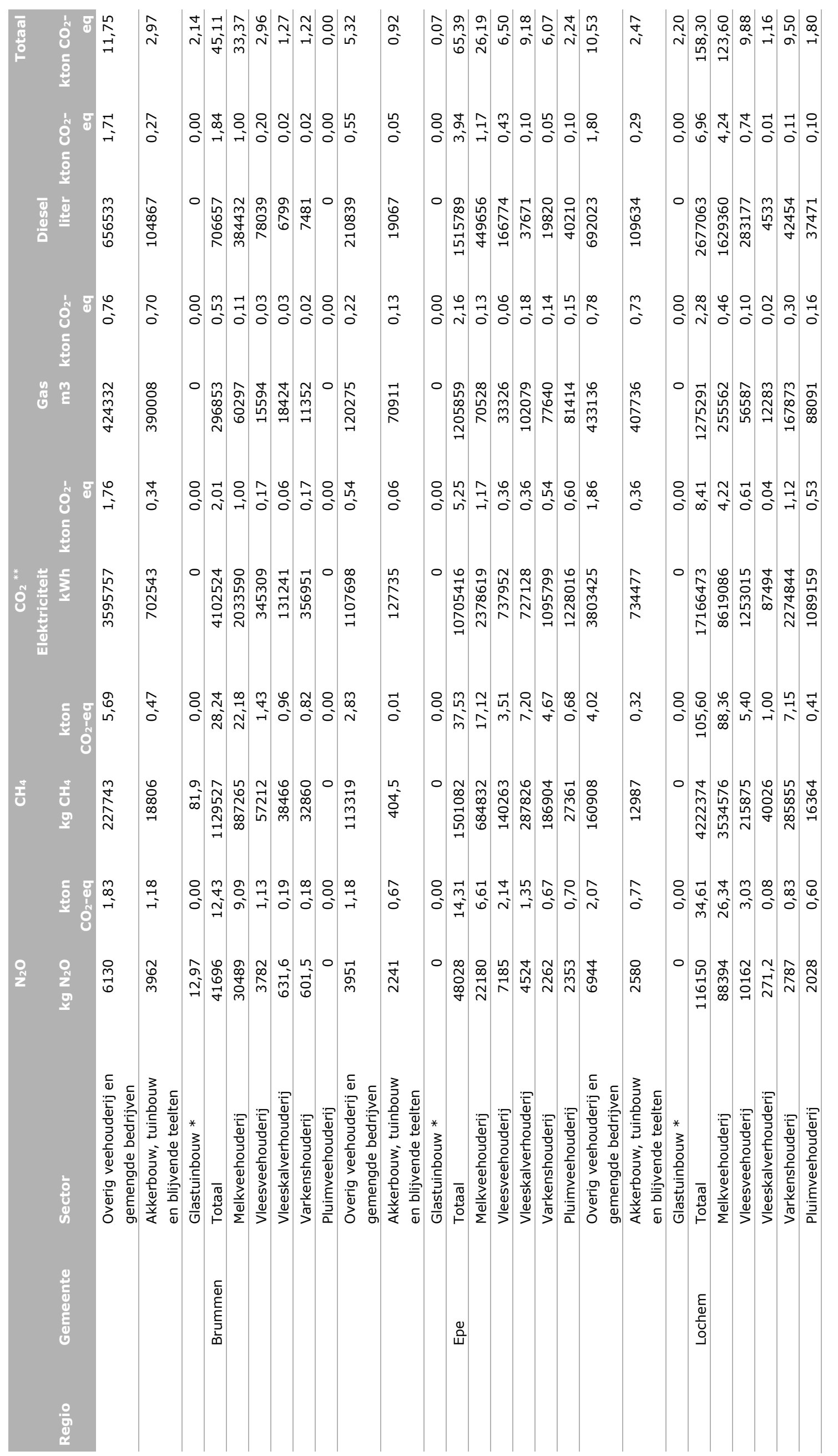


of

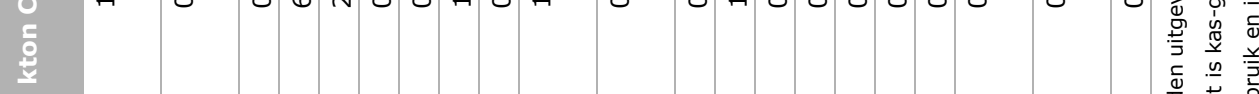

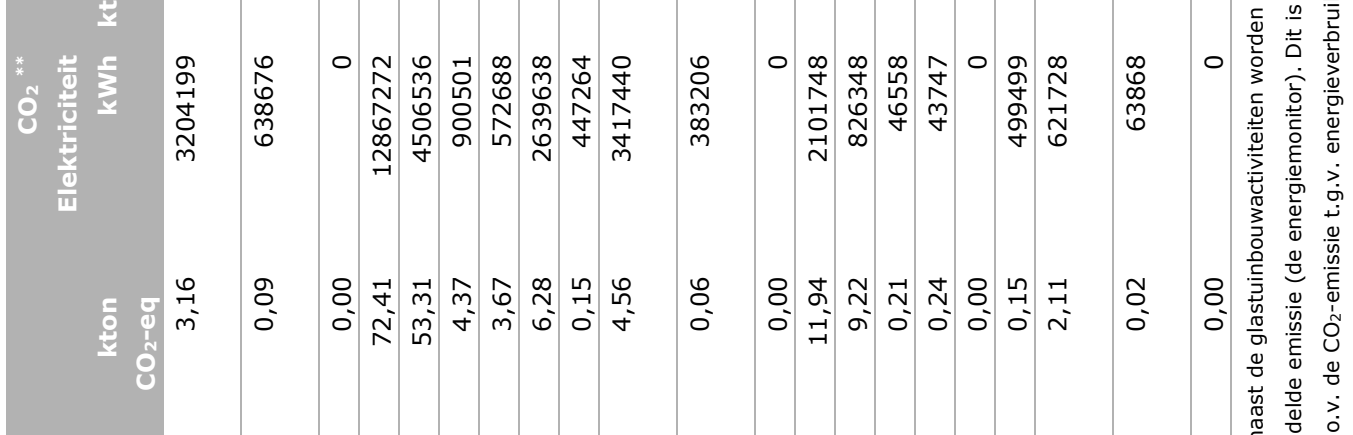

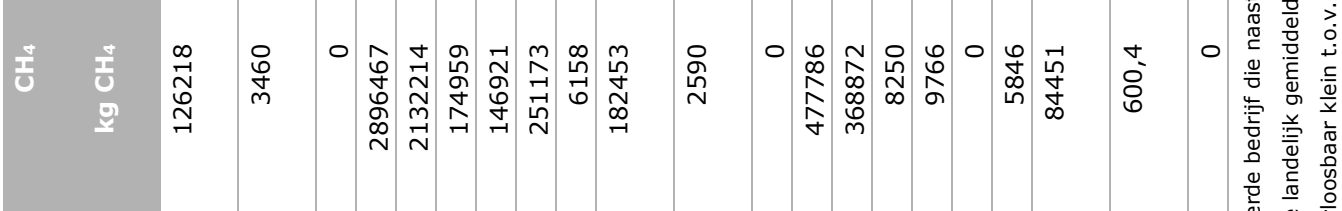

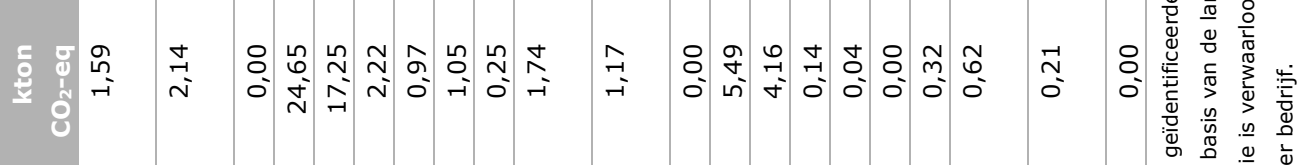

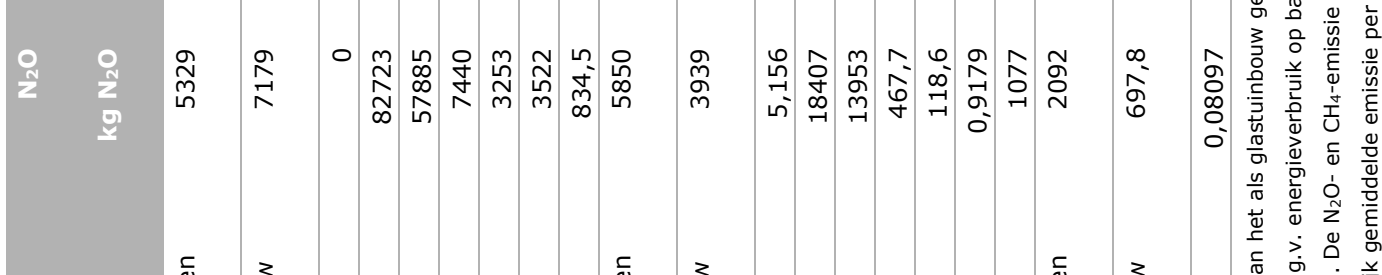

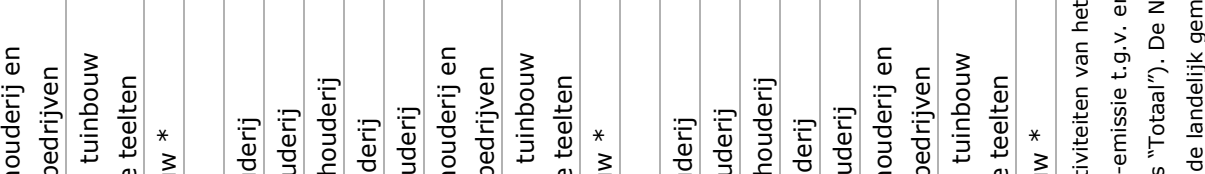

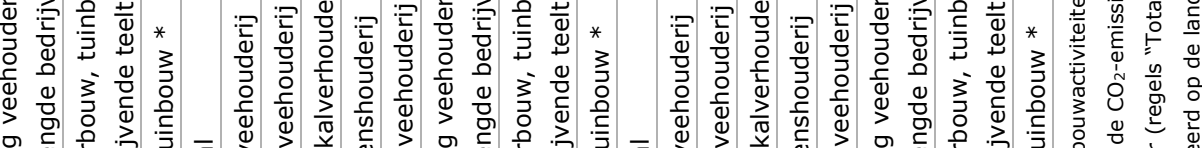

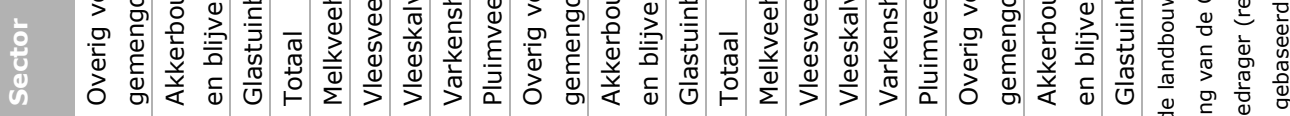

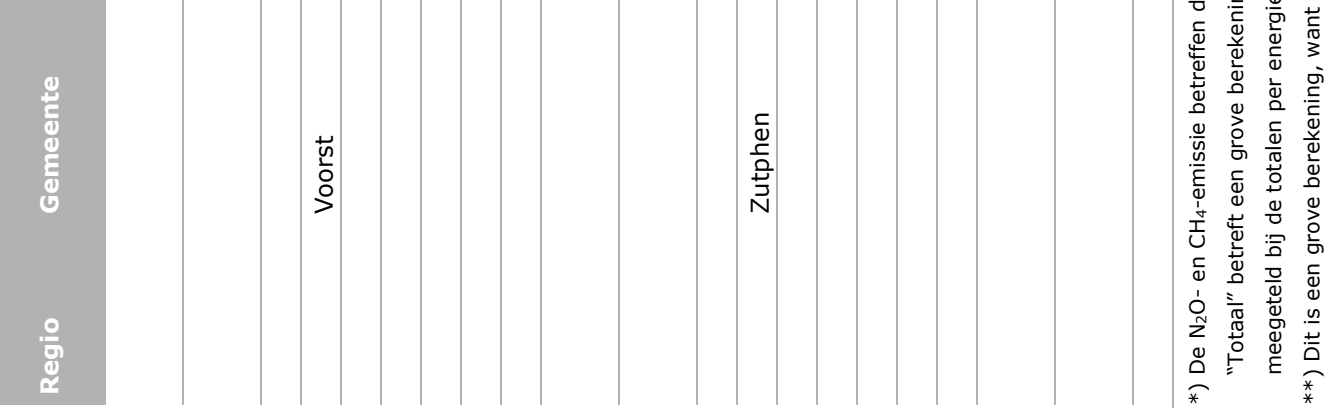


Wageningen Environmental Research Postbus 47

6700 AA Wageningen

T 0317480700

www.wur.nl/environmental-research

Wageningen Environmental Research Rapport 2947

ISSN 1566-7197
De missie van Wageningen University \& Research is 'To explore the potential of nature to improve the quality of life'. Binnen Wageningen University \& Research bundelen Wageningen University en gespecialiseerde onderzoeksinstituten van Stichting Wageningen Research hun krachten om bij te dragen aan de oplossing van belangrijke vragen in het domein van gezonde voeding en leefomgeving. Met ongeveer 30 vestigingen, 5.000 medewerkers en 10.000 studenten behoort Wageningen University \& Research wereldwijd tot de aansprekende kennisinstellingen binnen haar domein. De integrale benadering van de vraagstukken en de samenwerking tussen verschillende disciplines vormen het hart van de unieke Wageningen aanpak. 



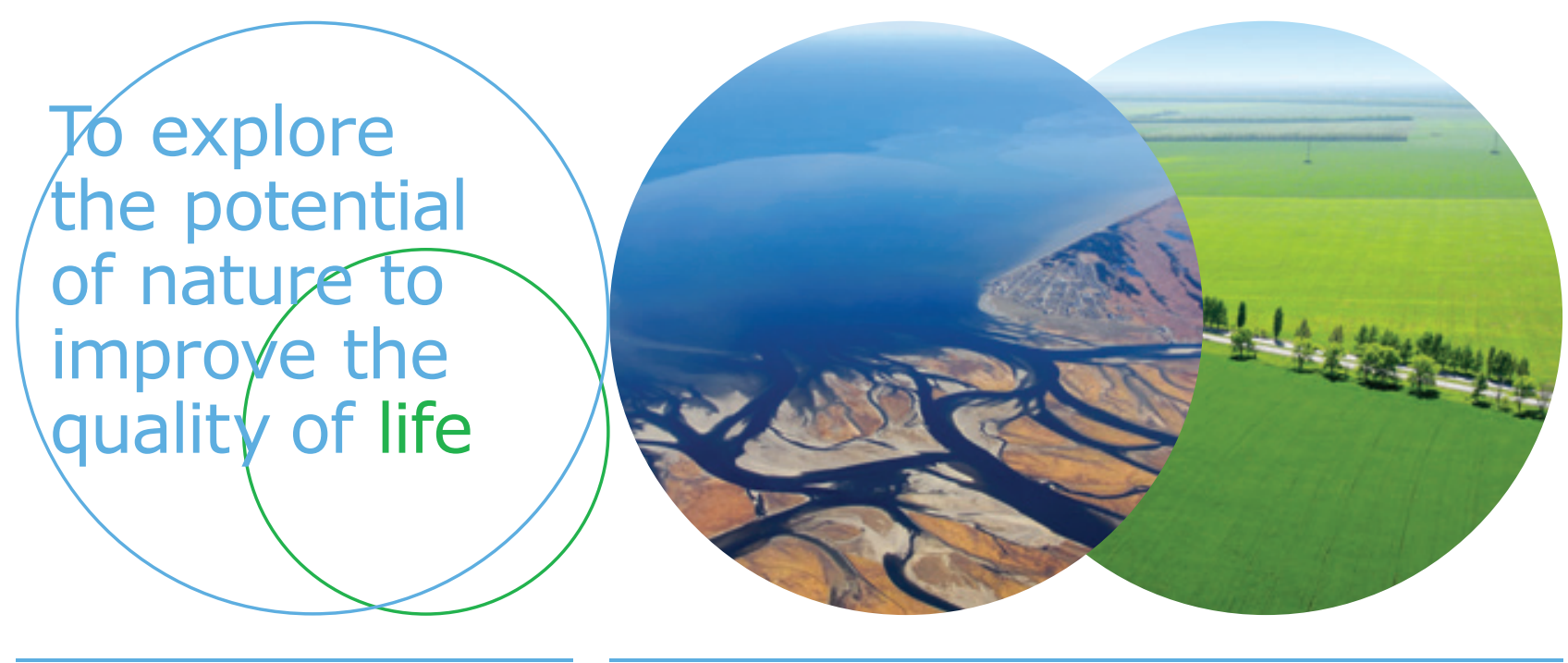

Wageningen Environmental Research Postbus 47

$6700 \mathrm{AB}$ Wageningen

T 317480700

www.wur.nl/environmental-research

Rapport 2947

ISSN 1566-7197
De missie van Wageningen University \& Research is 'To explore the potential of nature to improve the quality of life'. Binnen Wageningen University \& Research bundelen Wageningen University en gespecialiseerde onderzoeksinstituten van Stichting Wageningen Research hun krachten om bij te dragen aan de oplossing van belangrijke vragen in het domein van gezonde voeding en leefomgeving. Met ongeveer 30 vestigingen, 5.000 medewerkers en 10.000 studenten behoort Wageningen University \& Research wereldwijd tot de aansprekende kennisinstellingen binnen haar domein. De integrale benadering van de vraagstukken en de samenwerking tussen verschillende disciplines vormen het hart van de unieke Wageningen aanpak. 